\title{
CARBONATE PLATFORM DEVELOPMENT IN AN INTRAOCEANIC ARC SETTING: COSTA RICA'S LARGEST LIMESTONE SEQUENCE - THE FILA DE CAL FORMATION (MIDDLE EOCENE TO LOWER OLIGOCENE)
}

\author{
EL DESARROLLO DE UNA PLATAFORMA CARBONATADA EN UN ARCO \\ INTRAOCEÁNICO: LA MAYOR SECUENCIA DE CALIZAS DE COSTA RICA - \\ FORMACIÓN FILA DE CAL (EOCENO MEDIO A OLIGOCENO INFERIOR)
}

\author{
Angela Bolz* and Claudio Calvo \\ Anna-Peters-Str. 51C, 70597 Stuttgart, Germany \\ *Author for contact: angelabolz@t-online.de
}

(Recibido: 04/04/2017; aceptado: 06/06/2017)

\begin{abstract}
The limestones of the Fila de Cal Formation build the largest carbonate platform sequence of Costa Rica extending over $180 \mathrm{~km}$ from southern Costa Rica into the Panamanian boarder area of David. The detailed limestone microfacies analysis and micropaleontologic dating based on the contained larger foraminiferal assemblages of 22 samples selected from the most representative exposures reveal three main carbonate facies: (1) Eoannularia eocenicabearing spiculite facies from the Middle Eocene, (2) large lepidocyclinid-nummilitid facies from the Upper Eocene lead by the Lepidocyclina chaperi-Lepidocyclina tobleri panamensis assemblage and (3) dominant Lower Oligocene Lepidocyclina yurnagunensis-Lepidocyclina undosa assemblage. These three biostratigraphically successive facies record circa 14 to 19 m.y. of continuous shallow-marine carbonate sedimentation in the Pacific frontal arc region of southern Costa Rica. During this time large communities of benthic organisms: larger foraminifera, calcareous algae, corals, bryozoans, mollusks and equinoderms rapidly grew in warm tropical waters to build the largest and long-lasting carbonate platform on the Costa Rican arc. The carbonate sedimentation ended abruptly with accumulation of thick volcaniclastic marine platform-to-slope deposits of the Térraba Formation. Tectonically, the Fila de Cal carbonate platform development coincides with rapid convergence rates of the Farallón plate beneath southern Central America leading to strong arc uplift and new widespread neritic environments. The correlation with contemporaneous carbonate arc sequences clearly indicates that primarily their proximity to the inner volcanic arc areas and strong subsidence in response to emerging volcanic edifices are probably the main factors that controlled growing and persistence of carbonate environments within the arc setting.
\end{abstract}

Keywords: Costa Rica, carbonate platform, larger foraminifera, intraoceanic arc, Eocene, Oligocene.

Bolz, A. and Calvo, C. (2018). Carbonate Platform Development in an Intraoceanic Arc Setting: Costa Rica`s Largest Limestone Sequence - The Fila de Cal Formation (Middle Eocene to Lower Oligocene). Revista Geológica de América Central, 58, 85-114. doi: $10.15517 /$ rgac.v58i0.32845 


\begin{abstract}
RESUMEN: Las calizas de la Formación Fila de Cal constituyen la mayor secuencia de plataforma carbonatada de Costa Rica al extenderse por más de 180 km, desde el río Savegre hasta la región de David en Panamá. El análisis detallado de microfacies y micropaleontológico de las asociaciones de macroforaminíferos de 22 muestras de roca provenientes de afloramientos representativos revelan tres facies carbonatadas principales: (1) espiculitas de Eoannularia eocenica del Eoceno Medio, (2) facies de grandes lepidociclinas y nummulites del Eoceno Superior caracterizada por Lepidocyclina chaperi-Lepidocyclina tobleri panamensis y (3) facies de Lepidocyclina yurnagunensis-Lepidocyclina undosa del Oligoceno Inferior (Rupeliense). Estas tres facies, bioestratigráficamente sucesivas, documentan alrededor de 14 a 19 M.a. de continua sedimentación carbonatada nerítica en la región frontal del arco. Durante este tiempo, grandes comunidades de organismos bentónicos: macroforaminíferos, algas calcáreas, corales, briozoos, moluscos y equinodermos crecieron en aguas tropicales cálidas para formar la plataforma más extensa y duradera de Costa Rica. La sedimentación carbonatada terminó de forma abrupta con la acumulación de depósitos volcaniclásticos de plataforma y talud de la Formación Térraba. Tectónicamente, el desarrollo de la plataforma coincidió con altas tasas de convergencia de la placa Farallón por debajo de América Central, que condujo a fuerte levantamiento del arco y extensas áreas neríticas. La correlación con secuencias carbonatadas contemporáneas indican que la proximidad de las plataformas al arco interno y la fuerte subsidencia en respuesta a la emersión de nuevos edificios volcánicos son probablemente los factores que determinaron el crecimiento y persistencia de ambientes carbonatados en arcos intraoceánicos.
\end{abstract}

Palabras clave: Costa Rica, plataforma carbonatada, macroforaminíferos, arco intraoceánico, Eoceno, Oligoceno.

\section{INTRODUCTION}

In the Late Cretaceous and Paleogene times the shallow-marine sedimentation within the Costa Rican arc was predominantly of carbonate origin. Carbonate environments emerged all over the arc to build small carbonate reefs, platforms and ramps (Calvo, 1987; Bolz and Calvo, 2002). In this study we analyze the limestone sequence of the Fila de Cal Formation exposed in southern Costa Rica. The significant larger foraminiferal-calcareous algal limestone of the Fila de Cal sequence records a climax episode of shallow-marine carbonate sedimentation. As we show in this study, the episode took place in the Eocene-Oligocene time leading to the formation of Costa Rica's largest carbonate platform sequence. Although several studies have focused on the Tertiary sedimentary forearc sequence of southern Costa Rica (Henningsen, 1966; Mora, 1979; Weyl, 1980; Phillips, 1983; Heywood, 1984; Yuan and Lowe, 1987), there is surprisingly little knowledge about the limestone sequence in particular. The reason is mainly because the study of limestones requires a proper sedimentologic, microfacies and micropaleontologic approach - our research deals with. The main goals of our study are (1) to determine the age of the Fila de Cal Formation by dating the larger foraminiferal assemblages of the most representative limestone exposures, (2) to determine the carbonate sequence sedimentology by analyzing the microfacies of limestones in conjunction with field observations and (3) to outline the origin and tectonic history of Costa Rica's largest carbonate platform sequence within the Tertiary arc, in particular what factors control the development of carbonate platform sedimentation in the intraoceanic arc setting.

\section{Tectonic Setting}

Costa Rica and Panama emerged from an intraoceanic island arc built on the western convergent boundary of the Caribbean plate where the former oceanic Farallón plate (precursor of the actual Cocos plate) subducted since the Cretaceous (e.g. Lundberg, 1991; Calvo and Bolz, 1994). Today's convergent structure off southern Costa Rica shows a buoyant subducting segment of the oceanic Cocos plate covered with ridges and seamounts (e.g. the Cocos ridge and Quepos plateau) that cause strong erosion along the inner wall of the MAT (Fig. 1) - where actually no accretion takes place (von Huene and Flüh, 1994; Hinz et al. 1996). The study area locates in the inner forearc coastal range of southern Costa Rica (also known as the Térraba trough), more precisely in the Río Grande de Térraba area (Fig. 1 and 2). 


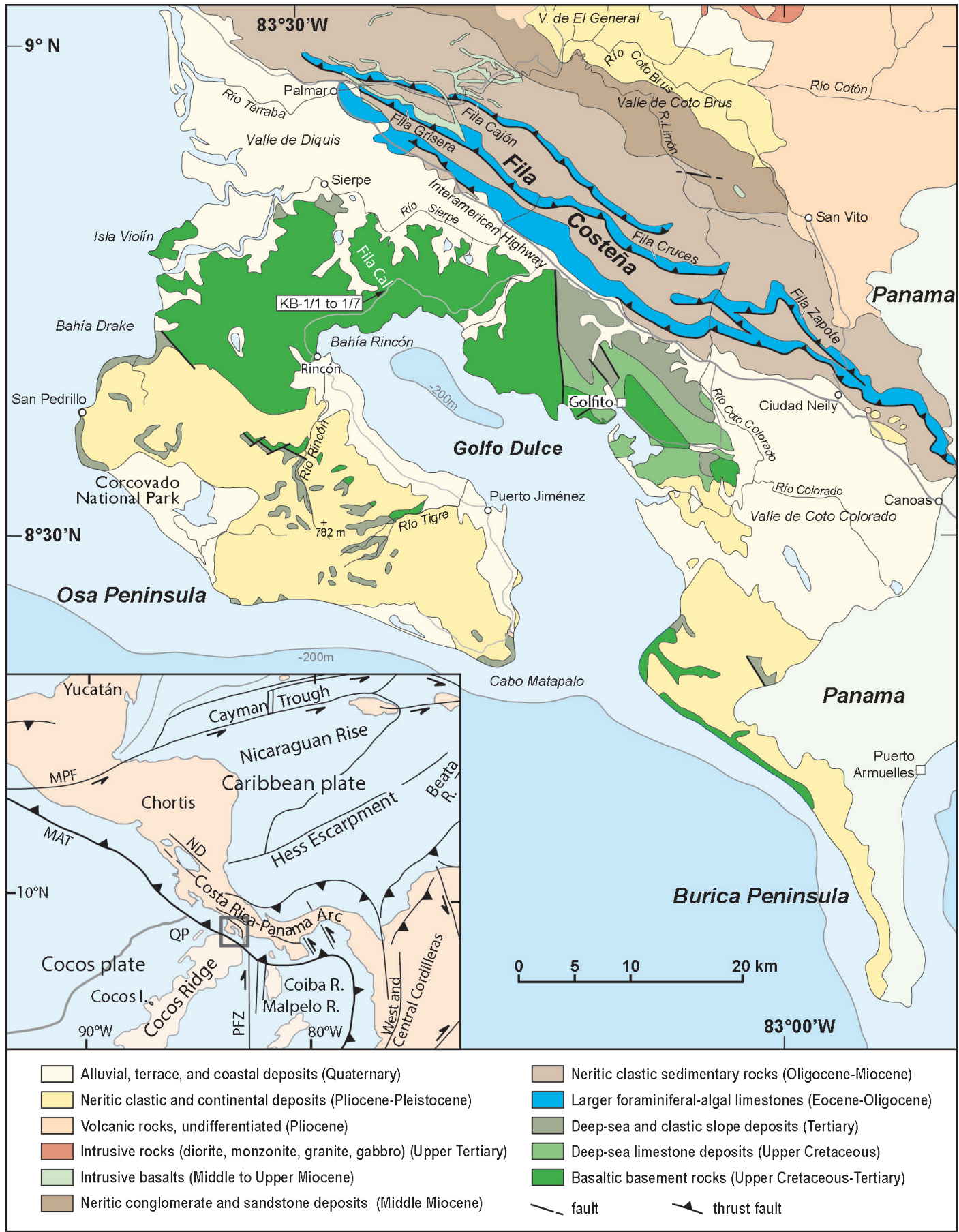

Fig. 1: Geologic and tectonic framework of the study area. The geologic map of southern Costa Rica is according to Mora (1979), Lew (1983), Berrangé (1989), Di Marco (1994) and compilation by Tournon and Alvarado (1995). Lithology modified after new findings. Inset map shows the tectonic framework of southern Costa Rica within the convergent plate margin of southern Central America (MPF-Motagua-Polochic Fault; MAT-Middle America Trench; ND-Nicaragua Depression; QP-Quepos Plateau; PFZPanama Fracture Zone). 


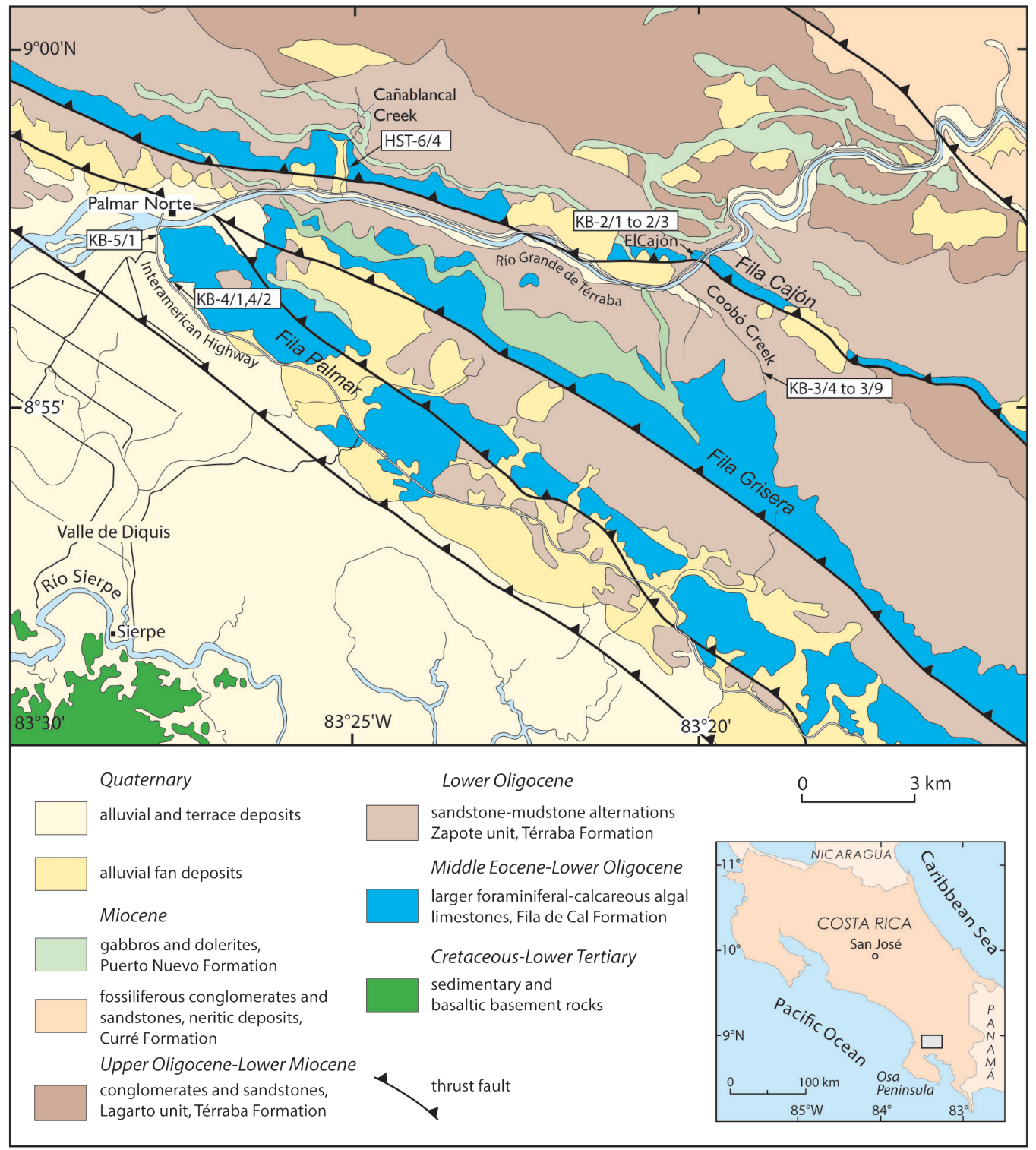

Fig. 2: Geologic map of the study area in the Río Grande de Térraba region, southern Costa Rica. Modified after Mora (1979) and compilation by Tournon and Alvarado (1995). The map contains the rock sample locations of the study.

The Tertiary sedimentary rock sequence exposed there builds the NW-SE striking coastal range named the Fila Costeña (Fig. 1). This mountain range is about $20 \mathrm{~km}$ wide and 180 $\mathrm{km}$ long, extending from the Savegre river valley, located on the western Pacific coast of Costa
Rica (Henningsen, 1966; Mora and Valdés, 1984), into the southwestern Panamanian border area of David (Fig. 1). The range borders NE to the intramountain El General and Coto Brus valleys and the following intrusive Talamanca Cordillera and SW to the forearc basement area of Golfito, Osa 
and Burica peninsulas, known as the uplifted outer arc (e.g. Lew, 1983). The Fila Costeña exposes the largest shallow-marine carbonate platform sequence known in Costa Rica: the Fila de Cal limestones - named the David Formation in Panama (Domínguez, 1978; Weyl, 1980).

The structure of the coastal mountain range resulted from thrust fault tectonics (Mora, 1979; Rivier, 1985). The tectonic movement pushed the entire Paleogene sedimentary rock sequence southwestward to build three main parallel striking limestone ridges, called filas. On the lower SW flanks of the carbonate ridges, steep faults thrust the limestones over the younger siliciclastic sedimentary rocks of the Térraba Formation, while on the opposite NE ridge flanks, the younger rocks conformably overlie the limestones (Fig. 2). The rising of the Talamanca Cordillera in northeastern and the forearc deformation resulted from arriving of the Cocos ridge are both thought to have caused the Fila Costeña thrust mountain (Mora, 1979; Rivier, 1985; Heywood, 1984; Stichler et al. 2007).

\section{Stratigraphic Framework}

The Tertiary sedimentary deposits of the Fila Costeña in the Río Grande de Térraba area build a remarkable circa 5000 to $5800 \mathrm{~m}$ thick sequence of larger foraminiferal limestones, siliciclastic rocks, including marls, mudstones, siltstones and conglomerates as well as fossiliferous and volcaniclastic sandstones and conglomerates (e.g. Dengo, 1960; Henningsen, 1966; Mora, 1979; Phillips, 1983; Heywood, 1984; Yuan and Lowe, 1987). The sequence age ranges from the Eocene to the Quaternary. The oldest deposits are the platform limestones of the Fila de Cal Formation, followed by marine siliciclastic deposits of the Térraba and Curré Formations, continental deposits of the Paso Real Formation and Recent alluvial deposits. The study focuses on the Fila de Cal and Térraba Formations. The older Late Cretaceous-Tertiary basement rock suite and its sedimentary cover outcrop southwest from the coastal range in the area of Río Sierpe, Golfito and Osa Peninsula (Fig. 1).

\section{The Fila de Cal Formation}

Dengo (1962) originally grouped the limestones of the Fila Costeña within the stratigraphic unit El Cajón of the Térraba Formation. Later, Henningsen (1966) followed by Mora (1979), Phillips (1983), Heywood (1984) and Yuan and Lowe (1987) separate the El Cajón unit from the Térraba Formation to include it within the Brito Formation. Such approach is in our opinion an issue. The Brito Formation in the type locality of southern Nicaragua is a coarse-grained deepsea slope sequence where carbonate rocks only consist after our observations of small deposits of resedimented shallow-water limestones. In contrast, the Fila de Cal limestones do build a significant thick carbonate platform sequence. Considering its thickness and significance, Calvo (1987, p. 147-148, fig. 34) formally introduced the new stratigraphic unit Formación Fila de $\mathrm{Cal}$, after the original name (calizas de Fila de $\mathrm{Cal}$ ) used to mention the limestone sequence in the study area (e.g. Weyl, 1980). More recently stratigraphic schemes for Costa Rica incorporate this term into their stratigraphic charts and maps (e.g. Sprechmann et al., 1994). In terms of stratigraphic nomenclature, new biostratigraphic results and previous geologic mapping (Mora, 1979) (Fig. 2) demonstrate the limestones of Fila Costeña build in fact a large long-term carbonate platform sequence and a proper stratigraphic unit in southern Costa Rica that should not longer be considered part of the southwest Nicaraguan Brito Formation.

The Fila de Cal Formation is a bioclastic carbonate sequence of circa $400 \mathrm{~m}$ thickness (Mora, 1979) we newly dated in this study from the Eocene to Oligocene and stratigraphically arranged in the El Cajón and Palmar Sur units, respectively. The bioclastic deposits build thickbedded to massive limestones and thin-bedded limestone strata, locally bearing marl and siltstone layers interbedded. The limestones show a welldeveloped karst system of large caves, most of them still unexplored (e.g. Ulloa et al., 2011). The formation contains the oldest strata - from the 
middle Eocene - within the Tertiary sedimentary sequence and is conformably overlain by the Térraba Formation. The youngest - lower Oligocene - strata of Fila Palmar section show a transitional contact to the Térraba Formation, marked by upward increasing intercalations of marls and siltstones that turn into predominantly siliciclastic series (Fig. 3). Henningsen (1966) and Mora (1979, p. 46) have previously described a similar transitional contact between the limestone and the lower Zapote unit of the Térraba Formation at other localities. The Savegre river limestones located in the western coastal region of Costa Rica and the David Formation limestones in Panama both are stratigraphic equivalents of the Fila de Cal sequence outlining its north and southern terminus, respectively.

\section{The Térraba Formation}

The Térraba Formation is a large coarseningupward sequence of siliciclastic and volcaniclastic deposits of Oligocene to Miocene age. Its cumulative thickness ranges between 2400 and $2700 \mathrm{~m}$ (Mora, 1979). The formation as Dengo $(1960,1962)$ originally defined it includes a heterogeneous sequence of carbonate platform and volcaniclastic slope deposits. The most suitable approach to the Térraba Formation reflecting the sequence coarsening- and shallowing-upward origin presents Mora (1979). Based on detailed mapping he outlined two successive units: the lower Oligocene Zapote Member, including monotonous series of siliciclastic platform and slope deposits and the upper Oligocene-lower Miocene Lagarto Member of coarse-grained volcaniclastic sandstones and conglomerates building braided channel and fan-delta deposits. The shallowing-upward deposits to the top of the Térraba Formation conformably pass over to the Miocene Curré Formation.

\section{METHODS}

The study includes detailed sedimentologic and stratigraphic field observations made on the most representative limestone exposures of the Fila de Cal Formation: El Cajón, Quebrada Cañablancal, Quebrada Coobó, Palmar Sur (on the south side of the Río Grande de Térraba) and Fila Cal (on the northern coast of Golfo Dulce) (Figs. 1 and 2). We have selected a total of 22 limestone samples from the former exposures for further microfacies analysis (Flügel, 1982) and micropaleontologic dating. All samples age determinations were made in thin sections $(5 \times 5 \mathrm{~cm}$ format) on the basis of their contained larger foraminiferal assemblages. The sample dating follows the biostratigraphy of larger foraminifera for the Gulf of Mexico, Caribbean and Central America regions by Butterlin (1981), Pécheux (1984) and others. The limestone textures are based on the combined classification of Dunham (1962) and Embry and Klovan (1971). The microfacies study also includes an additional petrologic analysis of accessory volcanic particles (rock fragments and crystals) contained within the limestone samples. The results are listed on Tables 1, 2 and 3 and illustrated on Figures 4, 5 and 6.

\section{RESULTS}

The limestones sampled from the studied exposures of the Fila de Cal Formation show a total of eight different microfacies types (MF1 to 8 , Tables 1 and 2) and three biostratigraphically successive larger foraminiferal assemblages. Table 3 resumes the samples age determinations, larger foraminiferal assemblages and depositional environments. The following microfacies description details the lithology and main biogenic grain composition, including the larger foraminifera, calcareous algae and significant accessory biogenic and volcaniclastic grains found in the limestone samples.

\section{El Cajón}

El Cajón, situated on the northwest riverside of the Río Grande de Térraba, is the most studied and visited limestone exposure of the Fila de Cal Formation - and therefore its type locality. The section directly exposed on the roadside consists 
of massive and thick-bedded light grey to white limestone deposits bearing larger foraminifera, red-algal fragments and rhodolites. They build part of the El Cajón anticline, a NW-SE oriented asymmetrical drag fold which limbs fall $60-70^{\circ} \mathrm{NE}$ and $80^{\circ} \mathrm{SW}$ and linked to the Rio Grande de Térraba thrust fault (Mora, 1979) (Fig. 2). All samples analyzed from El Cajón type section show a larger foraminiferal assemblage from the upper Eocene confirming previous dating by Malavassi (1961).

\section{Upper Eocene}

Lepidocyclina tobleri panamensis-Lepidocyclina chaperi facies

All microfacies MF1 samples KB-2/1, KB$2 / 2$ and $\mathrm{KB}-2 / 3$ build a compacted bioclastic packstone bearing mainly large lepidocyclinids, coralline algal fragments and rhodolites. The facies rich larger foraminifera assemblage comprises individuals of the species Lepidocyclina pustulosa pustulosa (Fig. 4D), Lepidocyclina tobleri panamensis, Lepidocyclina macdonaldi, Lepidocyclina ocalana, Lepidocyclina chaperi, Nummulites trinitatensis, Nummulites floridensis, Asterocyclina minima and Helicostegina polygyralis. In sample KB-2/3 A. minima and $L$. tobleri panamensis are dominant species. With exception of few tests of $2 \mathrm{~cm}$ length, most test dimensions lie below $1 \mathrm{~cm}$ in diameter.

The facies samples KB-2/1 and KB-2/2 also contain 0.5 to $3 \mathrm{~cm}$ thick composite rhodolites. The rhodolite form determines it core that usually consists of eroded or broken lepidocyclinid tests, thallus fragments of coralline algae or fragments of corals (Fig. 6B, C). The tight algal layers mostly of Mesophyllum sp. and Lithoporella sp. overgrowing the core are only 1 to $2 \mathrm{~mm}$ thick and never exceed $5 \mathrm{~mm}$. Some rhodolites show nodular algal thalli of Mesophyllum sp. and Archaeolithothamnium sp. Common rhodoliteencrusting organisms are foraminifera (including Eorupertia, Fabiania and large agglutinated lituolids), bryozoan colonies and serpulid individuals or colonies. The rhodolites (up to $15 \mathrm{~mm}$ in diameter) of sample KB-2/1 show abundant encrusting
Fabiania cassis individuals. Often rhodolites are strongly bored by microorganisms and infiltrated with biomicrite and algal pellets.

Further bioclastic grains are nodular algal thallus fragments, abundant coralline algal fragments (including Archaeolithothamnium sp., Lithothamnium sp., Mesophyllum sp., Lithoporella sp. and Corallina sp.) (Fig. 6E) small robust Amphistegina individuals, Gypsina vesicularis cubensis, Gypsina sp., Sphaerogypsina sp., small rotaliids, Fabiania cassis, Eorupertia sp. Ostracods, miliolids, small benthic and planktonic foraminifera as well as fragments of codiacean (Halimeda sp.) and dascycladacean algae, equinoderms and mollusks are common accessory grain constituents. Some biogenic grains display iron-hydroxide rinds and impregnations indicating weathering. Dolomite and saturated contacts also occur.

\section{Quebrada Cañablancal}

The Cañablancal creek, located on the north river side of the Rio Grande de Térraba (Fig. 2), exposes deformed carbonate platform-slope strata. The limestones build centimeter to decimeter thick beds bearing larger foraminifera from the upper Eocene. The strata exhibit relatively small plunging drag folds, including an overturned fold linked by a secondary inverse fault and an asymmetrical fold showing chevron-like crest (Mora 1979, figs. 76, 77), probably produced at the base of the décollement as the limestones moved southwestward over younger siliciclastic strata of the Térraba Formation (Fig. 2).

\section{Upper Eocene}

Lepidocyclina tobleri panamensis-Lepidocyclina chaperi facies

The larger foraminifera microfacies MF 2 sample HST-6/4 (Tables 1 and 2) texturally comprises a compacted bioclastic grainstone bearing flat and partially eroded, deformed, or broken larger foraminifera tests set parallel to each other to delineate lamination as well as tallus 
Table 1

Foraminifera contained in Middle Eocene, Upper Eocene and Lower Oligocene platform limestones from the Fila de Cal Formation, Costa Rica.

\begin{tabular}{|c|c|c|c|c|c|c|c|c|c|}
\hline Sequence & \multicolumn{9}{|c|}{ Fila de Cal } \\
\hline Facies & \multicolumn{9}{|c|}{$\begin{array}{c}\text { Bioclastic larger foraminiferal-calcareous algal packstone-grainstones } \\
\text { and rhodolite-foraminiferal rudstones }\end{array}$} \\
\hline Microfacies (MF) & 1 & 2 & 3 & $4 a$ & $4 \mathrm{~b}$ & 5 & 6 & 7 & 8 \\
\hline $\mathrm{KB}^{-1}$ & $\begin{array}{l}2 / 1-2 / 3 \\
1 / 1-1 / 4\end{array}$ & $\begin{array}{c}\text { HST- } \\
6 / 4\end{array}$ & $3 / 9$ & $3 / 5$ & $3 / 5$ & $\begin{array}{l}3 / 4 \\
3 / 6 \\
3 / 8\end{array}$ & $3 / 7$ & $\begin{array}{c}3 / 2-3 / 3 \\
1 / 5\end{array}$ & $\begin{array}{c}5 / 1 \\
4 / 1-4 / 2 \\
1 / 6-1 / 7\end{array}$ \\
\hline
\end{tabular}

\section{Foraminifera}

Nummulites panamensis

Nummulites trinitatensis

Nummulites floridensis

Helicostegina polygyralis

Helicostegina polygyralis paucispera

Amphistegina floridana

Amphistegina sp.

Asterocyclina sp.

Asterocyclina minima

Lepidocyclina (N.) macdonaldi

Lepidocyclina (L.) yurnagunensis

Lepidocyclina (L.) yurnag. morganopsis

Lepidocyclina (E.) undosa

Lepidocyclina (N.) pustulosa pustulosa

Lepidocyclina (N.) tobleri panamensis

Lepidocyclina (Nephr.) chaperi

Lepidocyclina (Nephr.) vaughani

Lepidocyclina (N) ocalana

Lepidocyclina sp.

Fabiania cassis

Gypsina vesicularis cubensis

Gypsina sp.

Eoannularia eocenica

Sphaerogypsina sp.

Neorotalia sp.

Eorupertia sp.

Victoriella $\mathrm{sp}$.

Planorbulina sp. 
Table 1

Foraminifera contained in Middle Eocene, Upper Eocene and Lower Oligocene platform limestones from the Fila de Cal Formation, Costa Rica.

\begin{tabular}{|c|c|c|c|c|c|c|c|c|c|}
\hline Sequence & \multicolumn{9}{|c|}{ Fila de Cal } \\
\hline Facies & \multicolumn{9}{|c|}{$\begin{array}{l}\text { Bioclastic larger foraminiferal-calcareous algal packstone-grainstones } \\
\text { and rhodolite-foraminiferal rudstones }\end{array}$} \\
\hline Microfacies (MF) & 1 & 2 & 3 & $4 a$ & $4 \mathrm{~b}$ & 5 & 6 & 7 & 8 \\
\hline Sample no. KB- ${ }^{1}$ & $\begin{array}{l}2 / 1-2 / 3 \\
1 / 1-1 / 4\end{array}$ & $\begin{array}{l}\text { HST- } \\
6 / 4\end{array}$ & $3 / 9$ & $3 / 5$ & $3 / 5$ & $\begin{array}{l}3 / 4 \\
3 / 6 \\
3 / 8\end{array}$ & $3 / 7$ & $\begin{array}{l}3 / 2-3 / 3 \\
1 / 5\end{array}$ & $\begin{array}{c}5 / 1 \\
4 / 1-4 / 2 \\
1 / 6-1 / 7\end{array}$ \\
\hline \multicolumn{10}{|l|}{ Foraminifera } \\
\hline Small rotaliids & • & & • & & & • & • & • & • \\
\hline Miliolids & - & • & • & • & - & & & & • \\
\hline Brown altered miliolids & & & & & & & & & • \\
\hline Agglutinated foraminifera & - & & & - & & - & - & • & - \\
\hline Small benthic foraminifera & • & & - & - & - & • & • & • & - \\
\hline Planktonic foraminifera & • & • & • & - & - & & • & • & $\bullet$ \\
\hline
\end{tabular}

- Occurrence determined in thin sections

${ }^{1}$ Sample description and location in text and on Figures 1 and 2.

fragments of crustose coralline algae. Stylolites are common. The dominant larger foraminiferal assemblage species are Lepidocyclina tobleri panamensis (Fig. 4F), Lepidocyclina macdonaldi, Lepidocyclina chaperi, Asterocyclina minima and Nummulites floridensis, followed by Nummulites trinitatensis, Asterocyclina sp., Helicostegina polygyralis and small robust individuals of Amphistegina and few planktonic foraminifera. The assemblage dates the deposit from the Upper Eocene. In addition the grainstone facies contains abundant large algal thallus fragments of codiacean (Halimeda sp.) up to $6 \mathrm{~mm}$ long and melobesoidean (Archaeolithothamnium sp., Mesophyllum sp. and Lithothamnium sp.) (Fig. $6 \mathrm{~F}$ ), composite rhodolite, equinoderm and bryozoan fragments, miliolids, planktonic foraminifera and angular, partially in calcite and kaolinite altered plagioclase crystals. Common algal thallus- and rhodolite-encrusting organisms are bryozoans and foraminifera: Gypsina sp., Eorupertia sp and Fabiania sp. Between 5 and $10 \%$ of biogenic grains display red-browned iron-hydroxide grain outlines, pointing out to previous exposure to weathering conditions in source areas; that means the grains were altered under subaerial conditions before their resedimentation again into shallow-marine environment.

\section{Quebrada Coobó (Fila Grisera)}

The Coobó creek, an affluent flowing from the southeastern Grisera range into the Río Grande de Térraba, exposes the most complete biostratigraphic limestone record in the study area of Fila Costeña so far. The limestones consist of larger foraminiferal-algal deposits of light grey to beige color, conformably covered by centimeter to decimeter bedded volcaniclastic strata of the Térraba Formation. The samples collected from Coobó creek contain three different successive larger foraminiferal assemblages from the middle Eocene, upper Eocene and lower Oligocene. Microfacies samples record wide range of shallow-marine and open-platform to platform-slope environments (Table 3). 
Table 2

Calcareous algae and accessory biogenic and volcaniclastic grain constituents of Middle Eocene, Upper Eocene and Lower Oligocene platform limestones from the Fila de Cal Formation, Costa Rica.

\begin{tabular}{|c|c|c|c|c|c|c|c|c|c|}
\hline Sequence & \multicolumn{9}{|c|}{ Fila de Cal } \\
\hline Facies & \multicolumn{9}{|c|}{$\begin{array}{l}\text { Bioclastic larger foraminiferal-calcareous algal packstone-grainstones } \\
\text { and rhodolite-foraminiferal rudstones }\end{array}$} \\
\hline Microfacies (MF) & 1 & 2 & 3 & $4 \mathrm{a}$ & $4 b$ & 5 & 6 & 7 & 8 \\
\hline Sample no. KB- ${ }^{1}$ & $\begin{array}{l}2 / 1-2 / 3 \\
1 / 1-1 / 4\end{array}$ & HST-6/4 & $3 / 9$ & $3 / 5$ & $3 / 5$ & $\begin{array}{l}3 / 4 \\
3 / 6 \\
3 / 8\end{array}$ & $3 / 7$ & $\begin{array}{c}3 / 2-3 / 3 \\
1 / 5\end{array}$ & $\begin{array}{c}5 / 1 \\
4 / 1-4 / 2 \\
1 / 6-1 / 7\end{array}$ \\
\hline \multicolumn{10}{|l|}{ Calcareous Algae } \\
\hline Rhodolites & • & • & & & & • & & & \\
\hline Archaeolithothamnium sp. & • & $\bullet$ & & • & & - & $\cdot$ & • & $\bullet$ \\
\hline Lithothamnium sp. & • & $\bullet$ & & • & & - & & & \\
\hline Lithoporella sp. & • & & & • & • & • & & - & • \\
\hline Mesophyllum sp. & • & • & & - & • & • & - & • & • \\
\hline Corallina sp. & • & & & $\bullet$ & • & & & • & • \\
\hline Dascycladacean & • & & • & & & & & & \\
\hline Codiacean (Halimeda sp.) & • & • & & • & & & & & \\
\hline \multicolumn{10}{|l|}{ Other Biogenics } \\
\hline $\begin{array}{l}\text { Red-brown weathered } \\
\text { bioclastic grains }\end{array}$ & • & $\bullet$ & & & & & - & - & \\
\hline Coral fragments & - & & & & & & & & \\
\hline $\begin{array}{l}\text { Neomorphic bivalve } \\
\text { fragments }\end{array}$ & & & & • & & & & & \\
\hline Oyster shell fragments & & & • & & & & • & • & • \\
\hline $\begin{array}{l}\text { Mollusk fragments, } \\
\text { undfferentiated }\end{array}$ & • & & & & & & & & $\bullet$ \\
\hline Balanid fragments & & & & & & & • & • & • \\
\hline Equinoderm fragments & • & • & • & • & • & • & • & • & • \\
\hline Bryozoans & • & - & • & & & - & - & • & • \\
\hline Serpulids & • & & & • & & • & - & • & • \\
\hline Spicula & & & • & & & & & & \\
\hline
\end{tabular}

\section{Rock Fragments}

Bioclastic limestone grains

Basaltic fragments

Altered lava fragments

Differentiated lava fragments

Tuffaceous fragments 
Table 2

Calcareous algae and accessory biogenic and volcaniclastic grain constituents of Middle Eocene, Upper Eocene and Lower Oligocene platform limestones from the Fila de Cal Formation, Costa Rica.

\begin{tabular}{|c|c|c|c|c|c|c|c|c|c|}
\hline Sequence & \multicolumn{9}{|c|}{ Fila de Cal } \\
\hline Facies & \multicolumn{9}{|c|}{$\begin{array}{l}\text { Bioclastic larger foraminiferal-calcareous algal packstone-grainstones } \\
\text { and rhodolite-foraminiferal rudstones }\end{array}$} \\
\hline Microfacies (MF) & 1 & 2 & 3 & $4 a$ & $4 \mathrm{~b}$ & 5 & 6 & 7 & 8 \\
\hline Sample no. KB- ${ }^{1}$ & $\begin{array}{l}2 / 1-2 / 3 \\
1 / 1-1 / 4\end{array}$ & HST-6/4 & $3 / 9$ & $3 / 5$ & $3 / 5$ & $\begin{array}{l}3 / 4 \\
3 / 6 \\
3 / 8\end{array}$ & $3 / 7$ & $\begin{array}{c}3 / 2-3 / 3 \\
1 / 5\end{array}$ & $\begin{array}{c}5 / 1 \\
4 / 1-4 / 2 \\
1 / 6-1 / 7\end{array}$ \\
\hline \multicolumn{10}{|l|}{ Volcanic Crystals } \\
\hline Pumice fragments & & & & & • & & & • & - \\
\hline Green clay particles & & & & & & & • & • & • \\
\hline Cherts & • & & & & & & & • & - \\
\hline Plagioclase feldspar & - & • & & • & - & • & & - & • \\
\hline Pyroxene & & & & & & & & & • \\
\hline Quartz & & & & & & & - & - & • \\
\hline
\end{tabular}

- Occurrence determined in thin sections

1 Sample description and location in text and on Figures 1 and 2

\section{Middle Eocene}

\section{Eoannularia eocenica facies}

This particular microfacies MF3 sample KB3/9 (Table 1 and 2) consists of spicula-rich packstone bearing abundant planktonic foraminifera and well-preserved individuals of the middle Eocene larger foraminifera Eoannularia eocenica Cole and Bermúdez (Fig. 4A, B). Contents of sponge spicula and planktonic foraminifera range between 20 and $40 \%$ and 1 and $10 \%$, respectively. Further accessory biogenic constituents are small larger foraminifera (Asterocyclina sp. and Lepidocyclina sp.), flat nummulitids (including Nummulites trinitatensis), Amphistegina sp., Planorbitolina sp., small benthic foraminifera, including small rotaliids, miliolids and fragments of bryozoan, dascycladacean thalli (e.g. Cymopolia sp.), as well as bivalve shell and equinoderm plate fragments. The rock shows a grain-supported texture bearing micrite groundmass. Micrite also infiltrated successively in millimeter open joints. Some feldspar fragments and small black vesicular basaltic lava (up to $1 \%$ ) containing small plagioclase microlites are common accessory volcanic grains.

\section{Upper Eocene}

\section{Lepidocyclina tobleri panamensis-Lepidocyclina chaperi facies}

The sampled limestone rock KB-3/5 consists of two different textured microfacies: (1) a coarse-grained larger foraminifera and coralline algae bearing packstone (MF4a) and (2) a fine-grained laminated packstone (MF4b; Tables 1 and 2) bearing rip-up clasts and bioclasts from the former microfacies. The coarse-grained microfacies MF4a is clearly bimodal exhibiting larger foraminifera and coralline algae set in a fine-grained groundmass consisting of algal pellets, fragments of coralline algae and larger 
Table 3

Localities, sample ages, larger foraminiferal assemblages and depositional environments of platform limestones from the Fila de Cal Formation, southern Costa Rica.

\begin{tabular}{|c|c|c|c|}
\hline Localities and Samples ${ }^{1}$ & $\begin{array}{c}\text { Microfacies } \\
(\mathrm{MF})^{2}\end{array}$ & Larger Foraminiferal Assemblages & Carbonate Platform Environment \\
\hline \multicolumn{4}{|l|}{ El Cajón } \\
\hline \multicolumn{4}{|l|}{ Upper Eocene } \\
\hline \multicolumn{4}{|l|}{ Cañablancal creek } \\
\hline \multicolumn{4}{|l|}{ Upper Eocene } \\
\hline \multicolumn{4}{|l|}{ Coobó creek } \\
\hline \multicolumn{4}{|l|}{ Middle Eocene } \\
\hline \multicolumn{3}{|l|}{ Upper Eocene } & Open platform \\
\hline \multicolumn{3}{|l|}{ Lower Oligocene } & Shallow-marine shoals \\
\hline $\mathrm{KB}-3 / 2,-3 / 3,-3 / 7$ & 6,7 & L. yurnagunensis - L. undosa & Open platform to platform slope \\
\hline \multicolumn{4}{|l|}{ Palmar Sur } \\
\hline \multicolumn{4}{|l|}{ Lower Oligocene } \\
\hline $\mathrm{KB}-4 / 1,-4 / 2(1.5 \mathrm{~km}$ from the bridge $)$ & 8 & L. yurnagunensis - L. undosa & Open platform to platform slope \\
\hline \multicolumn{4}{|l|}{ Fila Cal } \\
\hline \multicolumn{4}{|l|}{ Upper Eocene } \\
\hline $\mathrm{KB}-1 / 1,-1 / 2,-1 / 3,-1 / 4$ & 1 & L. tobleri panamensis - L. chaperi & Shallow-marine shoals \\
\hline \multicolumn{4}{|l|}{ Lower Oligocene } \\
\hline $\mathrm{KB}-1 / 5,-1 / 6,-1 / 7$ & 7,8 & L. yurnagunensis - L. undosa & Open platform to platform slope \\
\hline
\end{tabular}

1 Sample description is in text and location on Figures 1 and 2.

2 Microfacies constituents listed on Tables 1 and 2.

foraminifera, small benthic foraminifera, miliolids, equinoderms and few planktonic foraminifera. Few small lava fragments bearing feldspar microlites occur. The main bioclastic constituents are partially eroded and broken tests of lepidocyclinids (including individuals of Lepidocyclina macdonaldi, Lepidocyclina chaperi, Lepidocyclina pustulosa pustulosa and Lepidocyclina tobleri panamensis), asterocyclinids, nummulitids (Nummulites floridensis) and rests of Eorupertia sp. and Fabiania cassis as well as nodular coralline and codiacean thalli. The larger foraminifera assemblage belongs to the Upper Eocene. The coralline thalli build a bunch of algal branches consisting mainly of Archaeolithothamnium sp. often overgrown by Lithoporella sp., foraminifera (Gypsina sp. and large agglutinated lituolids) and serpulids. Locally the thalli are strongly bored by microorganisms.

The fine-grained packstone microfacies MF4b bears few eroded Lepidocyclina tests, coralline algal fragments and large limestone rock fragments derived from erosion of the former microfacies MF4a. The contact between both microfacies is very irregular, truncated and clearly erosive. The biogenic constituents similarly consist of abundant small benthic foraminifera, few rests of larger foraminifera and corallinacean algae, algal pellets, equinoderm 
fragments, planktonic foraminifera and miliolids. Altered brown colored lava, angular tuff (bearing plagioclase phenocrysts), felsic lava and plagioclase crystal fragments are common accessory volcanic grains. The intergranular pore space shows micrite and clay groundmass.

\section{Lower Oligocene}

\section{Lepidocyclina yurnagunensis-Lepidocyclina undosa facies}

The limestone microfacies MF 5, 6 and 7 (Tables 1 and 2) determined in samples from Coobó creek belong to the lower Oligocene. The microfacies MF 5 samples KB-3/4, KB-3/6 and $\mathrm{KB}-3 / 8$ all mainly consist of crustose coralline algal and larger foraminiferal grainstones/packstones and rudstones, locally bearing large algal framework fragments and rhodolites. Sample KB-3/4 contains Lepidocyclina-cored rhodolites of Mesophyllum and Lithoporella. The rhodolites are up to $3 \mathrm{~cm}$ in diameter and display nodular partially bored algal thalli. The thin section of sample KB-3/4 transversally cuts through a bunch of algal branches of Mesophyllum; similar algal branches appear in large fragments ranging in size between 5 and $10 \mathrm{~mm}$ in sample KB-3/6 and 8 and $17 \mathrm{~mm}$ in sample KB-3/8. Often the crustose coralline algal frameworks, including the rhodolites, are deeply bored and infiltrated with biomicrite and secondary crystalline silts. Among the crustose algal layers appear competitive miscellaneous rhodolite builders: serpulid, foraminifera and bryozoan colonies (Fig. 6D). Some multispecific frameworks and framework fragments consist of Mesophyllum layers followed by encrusting serpulids, foraminifera (Gypsina sp., Planorbulina. sp) and finally Lithoporella layers. In addition, sample KB-3/8 shows conspicuous large Eorupertia sp. individuals, while sample KB-3/8 contains larger serpulid colonies. The bioclastic grains including algal branches and rhodolites consist of crustose coralline algal thalli, eroded larger foraminiferal tests and test fragments (including Lepidocyclina yurnagunensis, Lepidocyclina undosa, Amphistegina sp.,
Sphaerogypsina sp. and abundant Neorotalia sp., principally), equinoderms and rests of encrusting organisms (e.g. bryozoans, foraminifera). The volcanic grain content is low including few strongly weathered plagioclase crystal fragments only.

The microfacies MF 6 sample KB-3/7 (Tables 1 and 2) is a compacted bioclastic packstone bearing remarkable contents between 10 and 20 $\%$ of planktonic foraminifera (Fig. 5F), small rotaliids and larger foraminifera. The sample also bears angular to subangular fragments of resedimented bioclastic packstone (5\%) and eroded oversized algal thallus fragments $(3-5 \mathrm{~mm})$ of Mesophyllum sp. and Archaeolithothamnium sp., often encrusted by foraminifera (Gypsina sp. and Eorupertia sp.), serpulids and bryozoans. The foraminiferal assemblage comprises Neorotalia sp., Lepidocyclina yurnagunensis, Lepidocyclina sp., Lepidocyclina undosa, Amphistegina sp., Victoriella sp. and planorbulinids (Fig. 5F). Angular quartz crystals and green clay particles are common accessory constituents. Many planktonic foraminiferal tests are broken. Content of iron-hydroxide impregnated bioclasts ranges between 2 and $5 \%$.

The microfacies MF 7 samples KB-3/2 and KB-3/3 (Tables 1 and 2) are coarse-grained red algal-larger foraminiferal grainstone-rudstones bearing accessory green clay particles, volcanic grains and limestone fragments containing planktonic foraminifera. The biogenic grains comprise strongly bored melobesoidean thallus and rhodolite fragments, eroded lepidocyclinid tests and test fragments, including Lepidocyclina yurnagunensis, Lepidocyclina undosa (Fig. 5C), Lepidocyclina sp., Amphistegina sp. and Neorotalia sp. individuals. Some tests show again iron-hydroxide impregnations. Large coralline algal fragments of Mesophyllum sp. and Archaeolithothamnium sp., strongly bored and encrusted by foraminifera (e.g. Gypsina sp.), serpulids and bryozoan colonies range in size between 5 and $7 \mathrm{~mm}$ in sample KB-3/2 and 1-8 $\mathrm{mm}$ in sample KB-3/3. Locally biomicrite fills the bored pore spaces of algal thalli. Well-rounded green clay particles and impregnations are common. The volcanic grains consist of subangular lava, tuff and pumice fragments, few quartz 


\section{Térraba Sequence \\ (Lower Tertiary)}

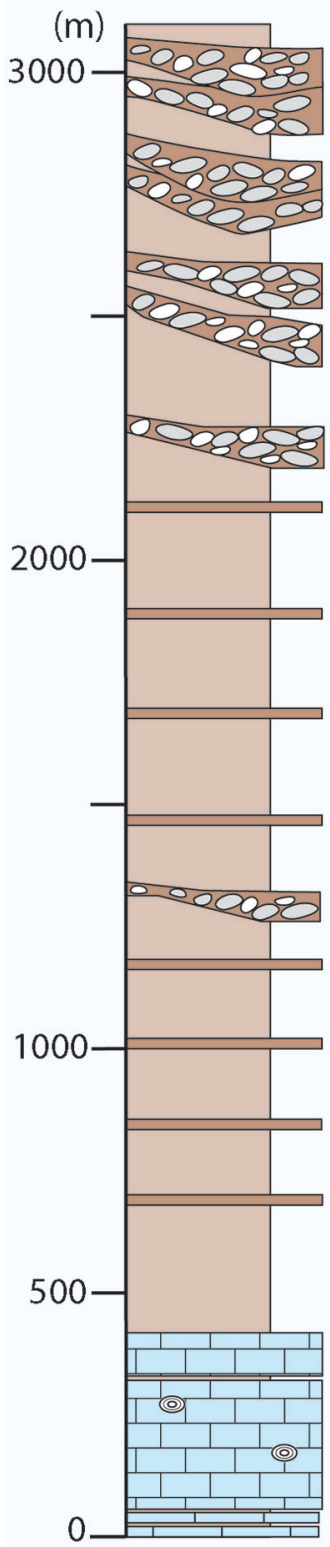

\section{Térraba Formation}

Lagarto Unit

\section{Legend}

volcaniclastic conglomerates

volcaniclastic sandstones

fine-grained sandstones and siltstones

thick-bedded to massive

rhodolite-foraminiferal limestones

larger foraminiferal-algal limestones

spiculite limestones bearing foraminifera

thrust fault

Zapote Unit

\section{Fila de Cal Formation}

L.yurnagunensis-L.undosa Palmar Sur Unit limestones (Lower Oligocene)

L.tobleri-panamensis-L.chaperi limestones (Upper Eocene)

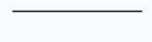

Eoannularia eocenica limestones (Middle Eocene)

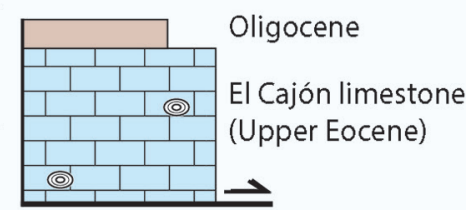

Fig. 3: Stratigraphic sections of the Lower Tertiary sedimentary rock sequence in the Río Grande de Térraba area of southern Costa Rica comprising the Fila de Cal and Térraba Formations. The Fila de Cal Formation sequence stratigraphically includes the Middle to Upper Eocene El Cajón unit and the newly dated Lower Oligocene Palmar Sur unit. Stratigraphic units of the Térraba Formation are from Mora (1979). Limestone age determinations based on their contained larger foraminiferal assemblages. Strata thickness is not at scale. 

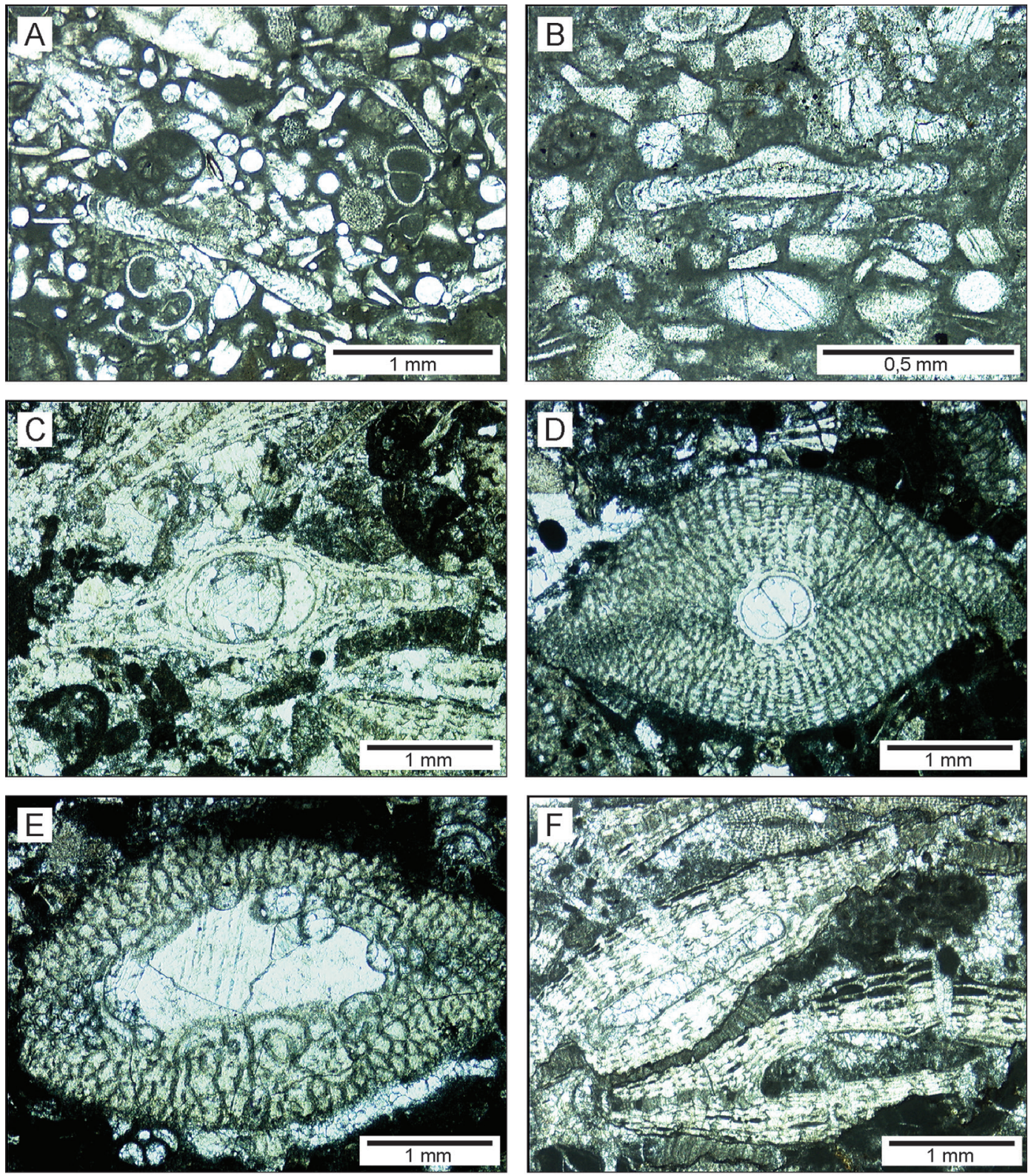

Fig. 4: Middle and Upper Eocene larger foraminiferal assemblages and limestone microfacies from the Fila de Cal Formation. A Middle Eocene microfacies from Coobó creek showing specimens of Eoannularia eocenica Cole and Bermúdez (upper right and left of view), planktonic foraminifera and abundant sponge spicula from deep-slope platform environments. Sample KB-3/9. B Eoannularia eocenica Cole and Bermúdez in axial section. Coobó creek. Sample KB-3/9. C Lepidocyclina (Nephrolepidina) chaperi Lemoine and R. Douvillé in axial section. Fila Cal. Sample KB-1/3. D Lepidocyclina (Neolepidina) pustulosa H. Douvillé in axial section. El Cajón. Sample KB2/1. E Lepidocyclina tobleri (Douvillé) subsp. panamensis (Cushman) in equatorial section showing the large embryo bordered by a collar of small globular chambers. El Cajón. Sample KB-2/1. F Large individuals of Lepidocyclina tobleri (Douvillé) subsp. panamensis (Cushamn) in axial section exhibiting their characteristic large embryos. Cañablancal creek. Sample HST-6/4. 

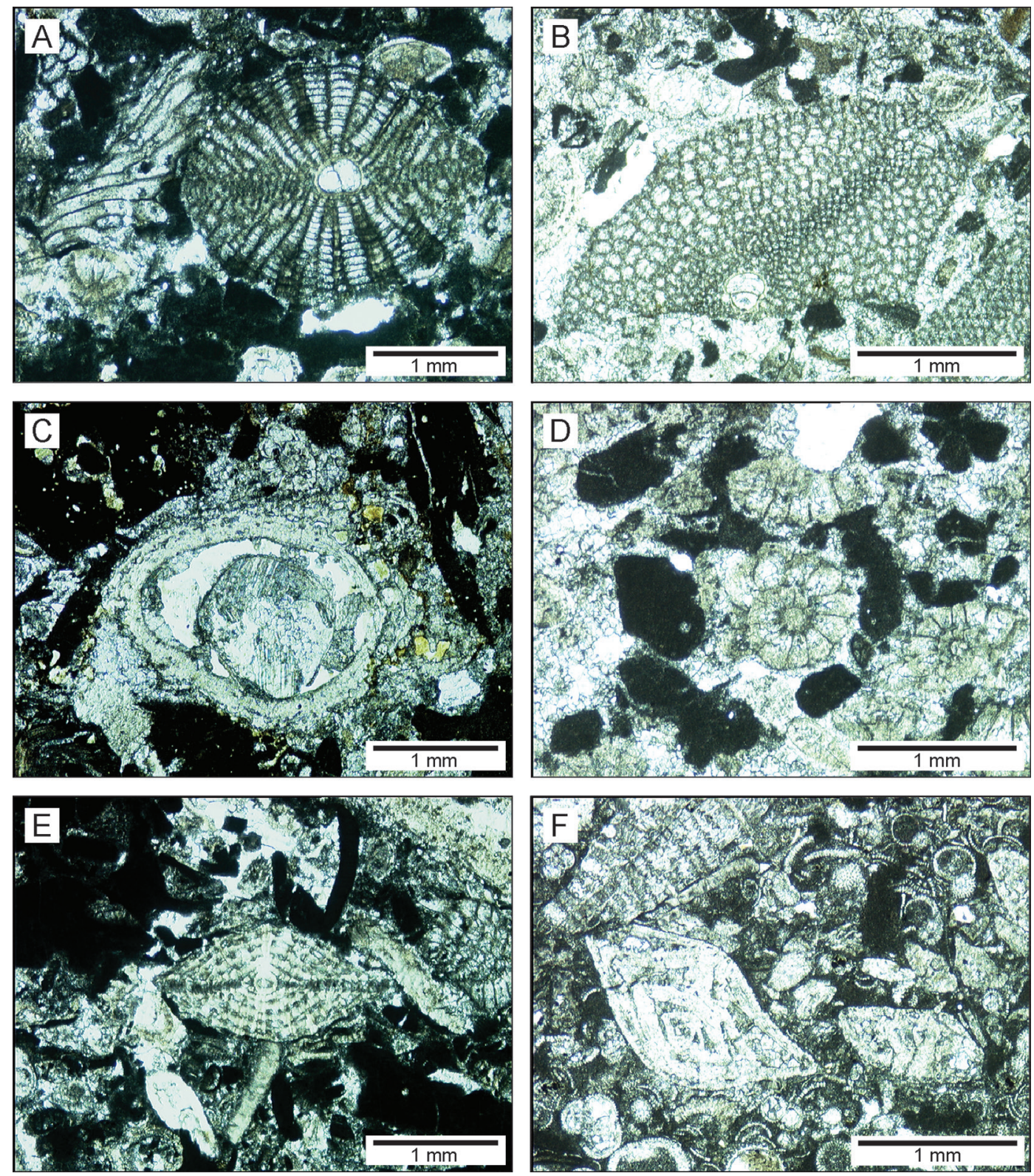

Fig. 5: Lower Oligocene larger foraminiferal assemblages and limestone microfacies from the Fila de Cal Formation. A Lepidocyclina (Lepidocyclina) yurnagunensis Cushman subsp. morganopsis Vaughan in axial section in the middle. Left in view a bryozoan colony fragment. Fila Cal. Sample KB-1/6. B Lepidocyclina (Lepidocyclina) yurnagunensis Cushman in axial section showing pseudo-nephrolepidine embryo. Fila Palmar sur limestone. Sample KB-4/1. C Detail of large juvenarium fragment of Lepidocyclina (Eulepidina) undosa Cushman in equatorial section. Note the thick embryonic chamber wall enclosing completely the proloculus. Palmar sur. Sample KB-4/2. D Neorotalia sp. and coralline algae fragments in grainstone from Coobó creek. Sample KB-3/7. E Helicostegina polygyralis (Barker) subsp. paucispira Barker and Grimsdale in axial section. Fila Cal. Sample KB-1/5. F Amphistegina floridana Cushman and Ponton (left), Lepidocyclina sp. (upper left) and small rotaliids (right) set in a groundmass bearing planktonic foraminifera, algal fragments and biomicrite; bioclastic foraminiferal packstone. Coobó creek. Sample KB-3/7. 

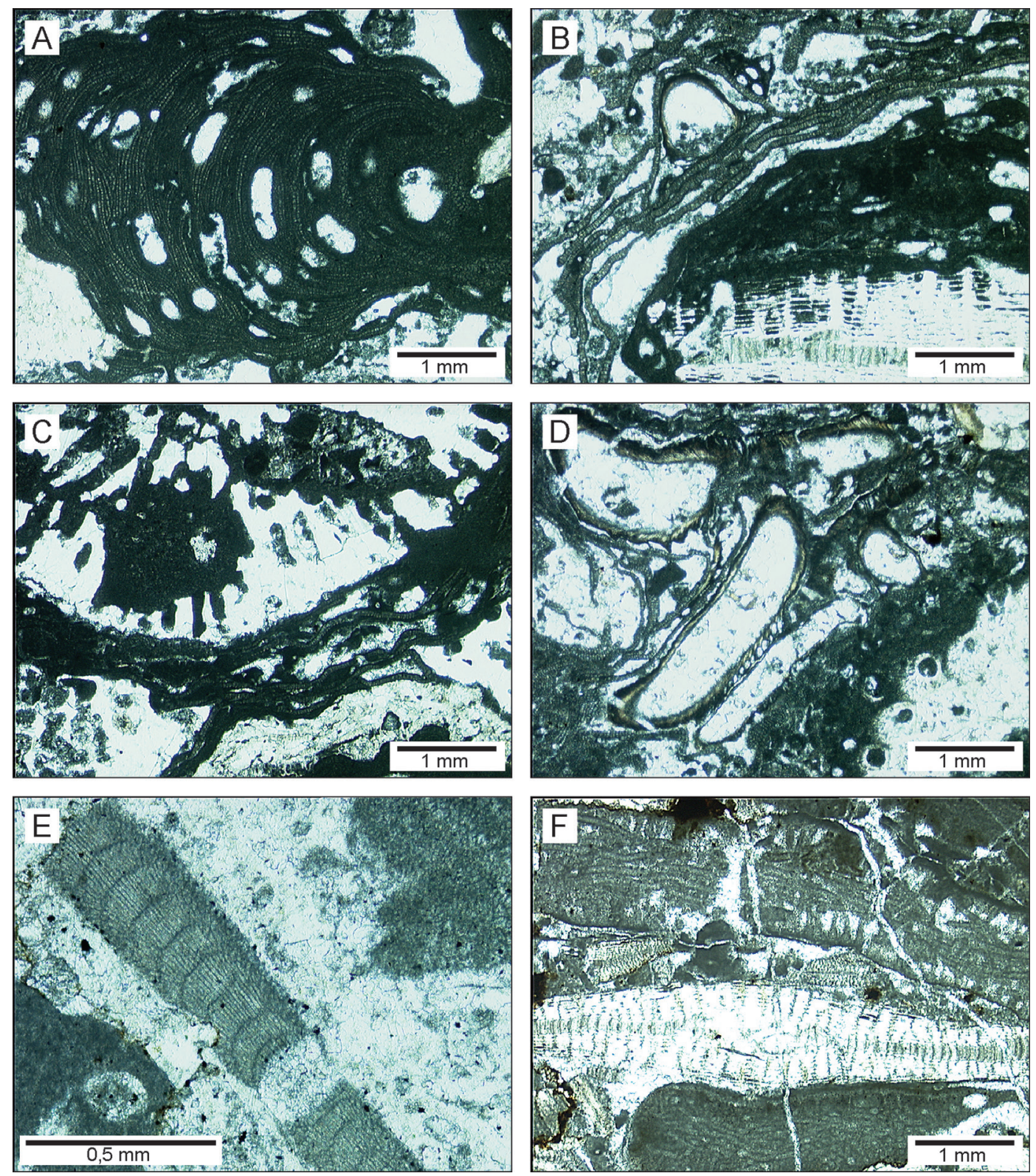

Fig. 6: Calcareous algae and other biogenic constituents contained in limestones from the Fila de Cal Formation. A Nodular thallus of corallinacean red algae, Mesophyllum sp., showing relatively large conceptacles in rhodolite facies. Fila Cal. Sample KB-1/4. B Crustose coralline algae (Mesophyllum sp.) overgrowing a large Lepidocyclina test to build a rhodolite; further thin layers of Lithoporella sp. and serpulids subsequently overgrow the former algae to become a composite rhodolite. Fila Cal. Sample KB-1/4. C Bored coral colony appears overgrown by thin-layered coralline algae (Lithoporella sp.). Coral framework fragment. Fila Cal. Sample KB-1/1. D Frameworks built up of bryozoan and serpulid colonies overgrown by Lithoporella sp. Coobó creek. Sample KB-3/4. E Thallus fragment of articulated coralline algae (Corallina sp.) in grainstone facies. Coobó creek. Sample KB-3/4. F Codiacean algae, Halimeda sp., in upper and lower part of the view; the two long sections exhibit well-developed central medulla and peripheral cortex area. In the middle appears Lepidocyclina sp. Cañablancal creek. Sample HST-6/4. 
crystals and up to $5 \%$ of angular to subangular, both weathered and fresh plagioclase crystals exhibiting twinning and zoning.

\section{Palmar Sur (Southeast Side of the Río Grande de Térraba)}

Directly behind the bridge over the Río Grande de Térraba on the Interamericana highway, the southwestern flank of the third limestone ridge of Palmar Sur exposes a circa $15 \mathrm{~m}$ thick section of carbonate deposits we newly date from the lower Oligocene (Fig. 2). The section consists of centimeter to decimeter thick laminated larger foraminiferal limestone strata in alternation with centimeter thick marls. Upward section they turn into series of alternating marls and siltstones Mora (1979) previously grouped into the lower to middle Oligocene Zapote unit of the Térraba Formation. Further circa $1,5 \mathrm{~km}$ southeast from the bridge on the highway more at least $5 \mathrm{~m}$ thick platform limestones outcrop. They resemble the former limestone strata, contain however only few marl intercalations. This section builds the top of the Fila de Cal Formation and its concordant boundary to the Térraba Formation.

\section{Lower Oligocene}

\section{Lepidocyclina yurnagunensis-Lepidocyclina undosa facies}

The microfacies MF 8 sample KB-5/1 from the bridge exposure is a bioclastic grainstone bearing small corallinacean fragments, larger foraminifera, volcanic grains and few marl-mudstone intercalations (Tables 1 and 2). The algae consist of fragments of Archaeolithothamnium sp., Mesophyllum sp. and Lithoporella sp. and minor Corallina sp. as well as rhodolite fragments. Lepidocyclina undosa, Lepidocyclina yurnagunensis, Neorotalia sp., Sphaerogypsina sp. and Amphistegina (e.g. Amphistegina floridana) are common foraminifera. The microfacies bears also accessory planktonic foraminifera. The volcanic grains made up to $10 \%$ of angular to subangular, weathered rather than fresh plagioclase crystals (exhibiting twinning and zoning), tuff, felsic lava and altered pumice fragments and few quartz and pyroxene crystals. Trace green clay grains are also present. The intercalated millimeter to centimeter thick marl-mudstone laminae bear planktonic foraminifera.

The limestone samples KB-4/1 and KB-4/2 from the exposure $1,5 \mathrm{~km}$ further east from the bridge on the Interamericana highway show a similar grainstone textured microfacies (Tables 1 and 2) consisting of larger foraminifera, rhodolite and melobesoidean thallus fragments. Common accessory constituents are planktonic foraminifera and volcanic grains. The benthic foraminifera comprise tests and test fragments, partially eroded, of Lepidocyclina yurnagunensis (Fig. 5A), Lepidocyclina vaughani and Neorotalia sp. (Fig. 5D). The non-carbonate grain assemblage consists of strongly weathered plagioclase crystals (1-2 \%), dark lava, tuff, well-rounded cherts and sedimentary green clay particles bearing planktonic foraminifera. The microfacies shows similarly thin hemipelagic marl-mudstone laminae interbedded.

\section{Fila Cal (Northern Coast of Golfo Dulce)}

The limestones from Fila Cal lie outside from the proper carbonate mountain area of Fila Costeña, on the flanks of the Fila Cal hill, directly on the northern coast of Golfo Dulce. The sampled exposure locates directly on the road from Piedras Blancas to Puerto Jiménez (Fig. 1). All seven samples studied show similar microfacies types and larger foraminiferal assemblages to those of limestones from the Fila de Cal Formation sequence; therefore we consider them stratigraphically belonging to the same formation. The larger foraminiferal assemblages record two different ages. 
Upper Eocene

Lepidocyclina tobleri panamensis-Lepidocyclina chaperi facies

Most samples collected from the Fila Cal exposure (KB-1/1 to KB-1/4) belong to the microfacies type MF1 (Table 1 and 2). They all consist of rhodolite, algal and larger foraminiferal packstone-grainstone facies. The larger foraminiferal assemblage includes individuals mostly from the upper Eocene: Lepidocyclina tobleri panamensis, Lepidocyclina (Nephrolepidina) chaperi (Fig. 4C), Lepidocyclina macdonaldi, Nummulites trinitatensis, Asterocyclina sp., Fabiania cassis, Eorupertia sp. and Gypsina vesicularis cubensis. In samples KB-1/1 and $1 / 3$ L. macdonaldi is abundant, while in sample $\mathrm{KB}-1 / 2 \mathrm{~L}$. tobleri panamensis is very common. The rhodolites exhibit lepidocyclinid cores (Fig. 6B). Sample KB$1 / 4$ contains composite rhodolites build of algal layers showing irregular thalli of Mesophyllum and Lithoporella, often incrusted by Gypsina sp., Eorupertia sp., large lituolids and serpulids (Fig. $6 \mathrm{~B})$. In addition sample KB-1/2 bears algal thallus fragments of Archaeolithothamnium sp. and Halimeda sp. The coral colonies, often strongly bored by microorganisms, are overgrown by melobesoidean algae (e.g. Lithoporella sp., Fig. 6C). Biomicrite infiltrated the porosity resulting from boring organism activity.

\section{Lower Oligocene}

\section{Lepidocyclina yurnagunensis-Lepidocyclina undosa facies}

The lower Oligocene samples from Fila Cal (KB-1/5, KB-1/7 and KB-1/6) correspond to microfacies types MF 7 and 8, respectively.

The microfacies MF7 sample KB-1/5 (Tables 1 and 2) is a coarse-grained red algallarger foraminiferal grainstone-rudstone bearing abundant melobesoidean algal thallus fragments, partially eroded and broken tests of larger foraminifera, equinoderm and bryozoan fragments and small rotaliids. The algal fragments are the main microfacies constituents, including abundant partially bored thallus fragments of Archaeolithothamnium sp., Mesophyllum sp., Lithoporella sp. and, minor thalli of Corallina sp. The foraminifera consist of individuals of Lepidocyclina yurnagunensis, few of Lepidocyclina (Eulepidina) undosa and Lepidocyclina sp., as well as accessory Planorbulinella sp. cf. rokae, Sphaerogypsina sp., Eorupertia sp., Reussella sp. and planktonic forms. The foraminiferal assemblage moreover contains resedimented well-preserved individuals of Helicostegina polygyralis (Barker) (Fig. $5 \mathrm{E})$ which occurrence we address later. Grain sizes of most biogenic fragments range between 2 and $7 \mathrm{~mm}$. The rock sample shows high porosity partially caused by boring activity of microorganisms, fracturing and dissolution of biogenic grains. In the open pore spaces infiltrated biomicrite and microcrystalline silts.

The microfacies MF8 sample KB-1/7 (Table 1 and 2) from Fila Cal is very similar to samples from Fila Palmar Sur exposures, consisting of bioclastic grainstone made up of abundant algal and equinoderm fragments as well as foraminifera and bryozoans. The foraminiferal assemblage comprises both tests and test fragments of small rotaliids, Lepidocyclina yurnagunensis, Lepidocyclina sp., Amphistegina sp., Planorbulinella sp. cf. rokae (detached individuals) and planktonic foraminifera. The abundant algal fragments include predominantly Archaeolithothamnium sp. and minor Lithoporella sp.; some fragments show bryozoan completely overgrown by algae and Gypsina sp. incrusting algae. The limestone texture is grainsupported without groundmass. The microfacies MF8 sample KB-1/6 (Table 1 and 2) shows nearly the same bioclastic composition of former sample, however its grain texture is coarser grained and clearly more compacted bearing locally micrite matrix. 


\section{Larger Foraminiferal Assemblages and Ages}

All larger foraminifera individuals contained in the Fila de Cal Formation samples, including those of the Fila Cal limestones, belong to American species known from the Gulf of Mexico, Central America, the Caribbean and northern South America. The taxonomic study reveals three different and successive assemblages within the 22 limestone samples from the main exposures we have analyzed in detail (Table 3 ).

\section{Eoannularia eocenica assemblage}

The Coobó creek sample KB-3/9 contains the oldest assemblage from the middle Eocene leading by the species Eoannularia eocenica Cole and Bermúdez. The well-preserved specimens, illustrated in Figure 4 A-B, show characteristic discoidal and flat tests; the early conch stage is thick lamellar. Annular chambers arranged in a single layer follow the bilocular embryo. They become slightly inflated towards the periphery; in some individuals the chambers of the last whorl become in axial cut slightly subangular. E. eocenica appears together with Nummulites trinitatensis (Nuttall), Lepidocyclina sp., Asterocyclina sp., small rotaliids and abundant sponge spicula and planktonic foraminifera. E. eocenica is a wellestablished marker species of the middle Eocene known originally from Cuba (personal remark L. Hottinger) (Cushman, 1948; Loeblich and Tappan, 1964; BouDagher-Fadel, 2008).

\section{Lepidocyclina chaperi-Lepidocyclina tobleri panamensis assemblage}

Lepidocyclina chaperi and Lepidocyclina tobleri panamensis build together with further common species (Asterocyclina minima, Helicostegina polygyralis, Nummulites floridensis and Lepidocyclina (Neolepidina) macdonaldi) the most common larger foraminiferal assemblage found in the Fila de Cal Formation (Table 3). Malavassi (1961) previously dated the assemblage at El Cajón site on the basis of the marker species Asterocyclina minima and Heterostegina ocalana. In our samples, A. minima and H. ocalana appear but not as often as L. chaperi and L. tobleri panamensis do; both are characteristic species in most upper Eocene samples analyzed.

Lepidocyclina (Nephrolepidina) chaperi Lemoine and R. Douvillé individuals are typically megalospheric; in equatorial section they show nephrolepidine embryo where the deuteroconch partially embraced the protoconch. In axial section, some particularly large megalospheric forms only exhibit few rows of lateral chambers (Fig. 4C).

Lepidocyclina (Pliolepidina) tobleri (Douvillé) subsp. panamensis Cushman - Eames et al. (1968) also quoted as Pliolepidina tobleri (Duovillé) subsp. panamensis (Cushman) - is a common lepidocyclinid foraminifera among the assemblages found in southern Central America and northern South America. The megalospheric pliolepidine specimens studied in limestone samples from the Fila de Cal Formation show in axial section inflated lepidocyclinid tests exhibiting a prominent large nucleoconch (Fig. 4F); in some axial sections the large embryo encloses few of the small embryonic chambers. In equatorial section the mostly large irregular pliolepidine embryo displays a series of as many as 6 to 10 small oval chambers arranged along its border building a collar; the embryo chamber wall is relatively thin (Fig. 4E). Sample KB-2/1 contains large specimens exhibiting $1.8 \mathrm{~mm}$ long nucleoconch.

Eames et al. (1968) considered some equatorial sections of specimens from samples 2 miles north of David (Panama) that Cole (1960, pl. 3, fig.1) previously illustrated to probably belonging to the subspecies panamensis rather than L. (Pliolepidina) tobleri (s.s.). As authors stated, L. tobleri subsp. panamensis Cushman differs from L. tobleri s.s. in having a more inflated test and a large pliolepidine embryo showing a thinner wall. These deposits belong to the David Formation (Domínguez, 1978). 
Lepidocyclina yurnagunensis-Lepidocyclina undosa assemblage

Lepidocyclina (Lepidocyclina) yurnagunensis Cushman is the leading species within the lower Oligocene assemblage followed by Lepidocyclina (Eulepidina) undosa Cushman. The assemblage is the second most often assemblage among the larger foraminifera of the Fila de Cal Formation (Table 3). We have also found specimens of L. yurnagunensis illustrated in Mora (1979, fig. 20, p. 50) as typical orbitoid foraminifera of El Cajón unit. In Palmar Sur samples they appear together with Lepidocyclina (Nephrolepidina) vaughani Cushman. The analyzed individuals of Lepidocyclina yurnagunensis exhibit in axial section lenticular test and welldeveloped low, broad and slightly arched lateral chambers. The embryo is bilocular mostly isolepidine (Fig. 5A) to pseudo-nephrolepidine in some cases (Fig. 5B) - forms we consider transitional to the true Lepidocyclina (Nephrolepidina) vaughani Cushman determined in the assemblage too. The specimens exhibiting short broad pillars (Fig. $5 \mathrm{~A})$ resemble the individuals of Lepidocyclina yurnagunensis from Ecuadorean samples Eames et al. (1968) assigned to Lepidocyclina yurnagunensis subsp. morganopsis Vaughan. These pillared forms often appear in grainstone and packstone facies, suggesting that the pillars contributing to a more stable conch could be resulted from the species adaptative strategy to survive in high energetic shallow-water environments.

In comparison to L. yurnagunensis, Lepidocyclina (Eulepidina) undosa Cushman is the less abundant species of the assemblage in the Fila de Cal limestones. Often their tests appear broken. All specimens of Lepidocyclina (Eulepidina) undo$s a$ show a large prominent megalospheric embryo, where the deuteroconch completely encloses the protoconch. In equatorial section the protoconch appears tangentially attached to the thick embryonic chamber (Fig. 5C). In axial section, the large megalospheric embryo shows a thick wall and a conspicuously large nearly rectangular shape.
In terms of biostratigraphic zones, the Oligocene assemblages determined in the Fila de Cal Formation limestones properly match the Lepidocyclina (Eulepidina)-Lepidocyclina (Lepidocyclina) subzone of Butterlin (1981) for the lower Oligocene (planktonic foraminiferal zones P18-P19, 33.7-30.3 Ma after Berggren et al. in Hardenbol et al. 1998). The exclusively appearance of these two genera together in absence of the genera Miogypsinoides and Heterostegina is a distinctive feature of lower Oligocene American assemblages (Butterlin, 1981) the Fila de Cal limestone samples also record - confirming Pécheux's early remark on the Oligocene foraminiferal assemblage.

\section{Helicostegina polygyralis (Barker) paucispira Barker and Grimsdale}

The occurrence of this species in lower Oligocene Fila Cal limestones is an issue we need to address in detail. In two thin sections of sample KB-1/5 we found 14 specimens with a preservation as good as the other lower Oligocene foraminifera species. Both thin sections exhibit representative axial cuts (Fig. 5E) of forms resembling Helicolepidina paucispira Barker and Grimsdale, in particular, those illustrated by Barker and Grimsdale (1936, plate 33, figs 4-6). The abundant specimens found in sample KB-1/5 show robust lenticular tests with prominent pillars; the early conch stage is small and clearly eoconuloid; the lateral chambers are well developed (Fig. 5E). H. paucispira is an upper Eocene marker species Cole (1960) considered synonym of Helicostegina polygyralis Barker - a similar species but with wider range from the upper middle to the upper Eocene (Butterlin, 1981). Cole's approach is in our opinion right, however, we retain the form paucispira (Barker) because of its stratigraphic value. Considering the fact $H$. polygyralis paucispira appears together with the characteristic lower Oligocene Lepidocyclina yurnagunensis-Lepidocyclina undosa assemblage, in the 
first instance it should be reworked from former upper Eocene deposits. Surprisingly, Eames et al. (1968) had previously made the same observation in samples from Ecuador, finding H. paucispira within a lower Oligocene larger foraminiferal assemblage containing even Lepidocyclina yurnagunensis subsp. morganopsis. Waiting for further evidence at that time, Eames et al. (1968, p. 302) kept back of extending the range of $H$. paucispira up into the early Oligocene, as authors explicitly stated. These two independent and coincident observations in Ecuador and now in southern Costa Rica open indeed the possibility that $H$. polygyralis paucispira did may have survived the Eocene-Oligocene boundary to continue into the early Oligocene in the tropical American realm and therefore it would not be restricted to the upper Eocene or middle-upper Eocene. In fact, the abundance of well-preserved $H$. polygyralis paucispira individuals within a lower Oligocene larger foraminiferal assemblage of the Fila Cal - where they belong together with L. yurnagunensis to the dominant species - in conjunction with Eames et al. (1968) previous observations are arguments enough for extending the species stratigraphic range into the lower Oligocene in the region.

\section{Sedimentology}

The microfacies study of the Fila de Cal Formation reveals predominantly bioclastic deposits that originally accumulated in marine carbonate platform environments. Paleoecologically, the bioclastic accumulations consist of thanatocoenoses of resedimented benthic carbonate organisms: larger foraminifera, calcareous algae, corals, bryozoans, mollusks and equinoderms. In conjunction with field observations the limestone microfacies record two dominant sedimentary environments: shallow-marine shoal and openplatform to platform-slope environments. The corresponding microfacies age determinations indicate both environments mostly took place contemporaneously during the Eocene and early Oligocene time to probably build part of a common large carbonate platform structure.

\section{Shallow-marine shoal environments}

The limestones thought to have accumulated in shoal environments consist of large thick-bedded packstone, grainstone and rudstone deposits that outcrop at El Cajón site, Coobó creek and Fila Cal hill. They made up of large and robust tests and fragments of larger foraminifera, calcareous algae fragments (mainly crustose coralline and minor articulated coralline and codiacean algae), corals, bryozoans, serpulids, mollusks and equinoderms; high accessory contents of encrusting detached and attached organisms recording clear and fresh marine water conditions are common. In particular, the rudstone microfacies types MF1 and MF5 (e.g. samples KB-1/1 and KB-3/4, Fig. $6 \mathrm{C}, \mathrm{D})$ bearing fragments of coral and bryozoanserpulid colonies both overgrown by crustose corallines point out to coral-algal and bryozoanserpulid-algal built-ups growing in shallow-marine environments linked to the bioclastic shoals. These carbonate bioconstructions were an important source of bioclastic debris found in those shoals. According to the Upper Eocene L. tobleri panamensis-L. chaperi microfacies (MF1) and the lower Oligocene Lepidocyclina yurnagunensis-Lepidocyclina undosa microfacies (MF1, 5), the shoal environments occurred in the Eocene and early Oligocene, coexisting with deeper platform environments (Table 3 ).

\section{Open-platform to platform-slope environments}

The predominantly centimeter- to decimeter-bedded limestone deposits of Palmar sur and Cañablancal and Coobó creeks show common microfacies types characteristic of deeper marine deposits accumulated in open marine platform and platform slope environments. The limestone microfacies consist of similar resedimented bioclastic material as the shoal deposits; they show however in addition higher amounts of smaller benthic foraminifera (e.g. Neorotalia and Rotalia) and accessory contents of planktonic foraminifera, sponge spicula and rip-up clasts. Such biogenic constituent assemblage means a longer and 
stronger transport of benthic bioclastic material up into deeper platform-slope environments. In detail the oldest, Middle Eocene, Eoannularia eocenica microfacies (MF3, Table 3) records mainly deeper open platform or platform slope environments as its significant contents of planktonic foraminifera and spicula indicate. Similar environments reveal the Upper Eocene L. tobleri panamensis-L. chaperi microfacies (MF2; Table 3) of Cañablancal creek and the lower Oligocene Lepidocyclina yurnagunensis-Lepidocyclina undosa microfacies (MF8, 9) both from Palmar Sur and Fila Cal hill (MF7, 8, 9; Table 3).

\section{Resedimentation of bioclastic materials}

Reworking or resedimentation of bioclastic materials is the most common sedimentary process the limestone microfacies of the Fila de Cal deposits record. Dominant larger-foraminifera accumulations are particularly susceptible to it, because of the postmortem higher hydrodynamic potential of flat, lenticular or discoidal foraminifera-test forms to be transported by water currents. The property of larger foraminifera to be easily displaced from their habitat makes the application of depositional models based on foraminifera test forms (e.g. Hallock and Glenn, 1986) to interpret larger-foraminiferal limestone very difficult if not unrealistic, as we have experienced in our study.

There are two types of sediment reworking observed: (1) reworking of clastic (bioclastic and minor volcaniclastic) materials from exposed areas into shallow-marine bioclastic shoal environments and (2) resedimentation of shallow-marine bioclastic debris into deeper outer platform and platform slope environments. In the first case, the microfacies shows accessory biogenic grains exhibiting iron-hydroxide outlines and intensively eroded and bored rhodolites, algal fragments and larger foraminifera tests and even weathered volcanic grains mixed within unaltered fresh bioclastic shoal material. Such accessory weathered biogenic grains also appear in deeper marine microfacies recording resedimentation of older carbonate debris into younger platform-slope environments. In the second case the microfacies shows commonly grainstone textures, lacking of groundmass, graded bedding in conjunction with rip-up clasts and significant contents of planktonic foraminifera pointing to strong resedimentation of shallow-marine bioclastic carbonate grains into deeper marine environments (e.g. outer platform and platform slope) by gravity transport mechanism, mainly grain flows and turbidity currents.

\section{Stratigraphic Units}

The detailed biostratigraphic and microfacies approach in conjunction with field observations reveal two main stratigraphic units within the Fila de $\mathrm{Cal}$ Formation sequence in the study area: the Eocene El Cajón unit and the Oligocene Palmar Sur unit (Fig. 3).

\section{El Cajón unit}

We redefine the El Cajón unit of Mora (1979) by including the two different successive Eocene bioclastic facies studied: a minor Middle Eocene Eoannularia eocenica-bearing spiculite facies and the dominant larger foraminifera facies of the Lepidocyclina tobleri panamensis-Lepidocyclina chaperi assemblage from the Upper Eocene (Priabonian). The unit mainly consists of massive to decimeter thick-bedded limestones accumulated in shallow-marine shoal and deeper openmarine to platform-slope environments as well. Bioclastic lepidocyclinid-nummilitid foraminifera and algal bearing limestones are the dominant lithology, comprising more than $90 \%$ of the Eocene deposits studied. The most representative unit exposure is the homonymous formation's type locality of the El Cajón site (Figs. 2 and 3).

\section{Palmar Sur unit}

The new defined Palmar Sur unit consists of decimeter thick-bedded bioclastic deposits of the Lepidocyclina yurnagunensis-Lepidocyclina undosa facies from the Lower Oligocene-Rupelian. 
The limestone unit series outcrop along the Fila Palmar (Figs. 2 and 3); the previously described exposures directly behind the Río Grande de Térraba Bridge build the type locality. Individual centimeter thick layers of marls and siltstones interbedded are common in this unit, especially in the top series they increase to conformably pass over to the Térraba Formation. Although deeper open platform and platform slope deposits dominate, the unit also includes shallow-marine shoal deposits (Table 3).

\section{DISCUSION}

\section{Origin and Tectonic History of the Fila de Cal Carbonate Platform}

The tectonic inner-forearc framework of the coastal thrust range suggests the Fila de Cal platform built along the Pacific frontal arc area (Fig. 1). The carbonate platform growing in the Middle Eocene to early Oligocene time coincides with rapid Farallón plate convergence under equatorial America between 48 and 37 Ma (Daly, 1989) and fast convergence rates (greater than $100 \mathrm{~km} / \mathrm{m} . \mathrm{y}$.) of the Farallón plate under North America between 75 and $40 \mathrm{Ma}$ (Engebretson et al. 1985). This longterm plate convergence led to strong uplift of the Costa Rican-Panamanian arc and consequently to the origin of new broader and extended neritic areas where the Fila de Cal platform evolved (Fig. 8A-B).

\section{Climax episode of carbonate sedimentation}

In marked contrast to further contemporaneous neritic arc areas where mostly restricted relatively small carbonate platforms and ramps developed (Calvo, 1987; Bolz and Calvo, 2002), the Fila de Cal sequence records indeed remarkable vast marine carbonate environments. Considering detailed limestone mapping (Mora, 1979) and time space of carbonate sedimentation, the platform sequence of Fila de Cal is the longest-lasting and largest carbonate platform in southern Central America. The three newly determined bio-stratigraphycally successive foraminiferal assemblages from the middle Eocene, upper Eocene and lower
Oligocene (Rupelian) mean circa 14 to 19 m.y. (Ogg et al. 2016) of continuous carbonate sedimentation along the Pacific frontal arc areas (Fig. 8B). Relatively stable and long-term marine carbonate conditions in warm tropical waters prevailed at that time to reach a climax of platform development no other limestone sequences in the region record.

\section{Drowned carbonate platform}

The carbonate platform growth declined in the early Oligocene with a dramatic change of sedimentary conditions from a carbonate to a true siliciclastic/volcaniclastic depositional environment, marked by accumulation of thick marine platform to slope deposits of the Térraba Formation (Fig. 8C). The Palmar Sur section of top of the Fila de Cal Formation documents the onset of siliciclastic conditions through intercalations of marls and siltstone layers within limestone strata, which turned upward into dominant siltstones series of the Térraba Formation. This section points to a drowned carbonate platform. In terms of sequence stratigraphy, the thick siliciclastic series following the drowned platform record a significant increase of accommodation space caused by strong subsidence (Fig. 8C). The dominant andesitic sediment composition and coarsening- and thickening-upward sequence trend (e.g. Henningsen, 1966; Mora, 1979) point to increasing subsidence rates probably in response to emerging volcanic arc areas.

The shallow-marine carbonate conditions disappear nearly completely in the Río Grande de Térraba area in the course of the early Oligocene. However, they apparently persisted in the southern region of Fila Zapote (Fig. 1) until the late Oligocene with further fossiliferous sandstones and larger foraminiferal limestones (calizas de río Claro) accumulating on former Eocene limestone deposits (Yuan, 1984).

\section{Stratigraphic Correlations}

The positive correlation of the Fila de Cal carbonate sequence with contemporaneous arc platform sequences of the Parritilla and Las Ánimas 
Formations in particular (Fig. 7) argue against the basement block tectonics Yuan and Lowe (1987) have proposed to explain the Tertiary sequence evolution in southern Costa Rica. In contrast, these three common drowned carbonate platform series conformably overlapped by thick siliciclastic and volcaniclastic deposits reveal an arc-wide tectonic history, probably caused by new emerging active volcanic areas. Such tectonic arc scenario could be resulted as we mentioned before from higher convergence rates of the Farallón plate under the Costa Rican arc during Eocene and Oligocene times.

\section{Control of volcaniclastic sedimentation on arc carbonate platform development}

In terms of carbonate sedimentation, the stratigraphic correlation of Figure 7 makes also clear the strong and determinant influence volcanic arc activity has had on carbonate platform growth and development within the Tertiary intraoceanic arc setting. In all sequences the accumulation of thick volcaniclastic deposits completely terminates the carbonate platform environments. Moreover, the carbonate sequences age comparison indicates their proximity to the volcanic inner arc areas - where volcaniclastic input dominates the sedimentary environment - likely controlled extension and persistence of carbonate environments (Fig. 7). The closer to the volcanic areas, the earlier the carbonate sedimentation declines: so in the Parritilla Formation sequence, located within the inner arc, the carbonate development was restricted to the Middle Eocene (Bolz and Calvo, 2002), while Las Ánimas limestone sequence, situated on the eastern inner arc, reached the Upper Eocene (Rivier, 1973; Fernández, 1987) (Fig. 7). In the Pacific frontal arc of southern Costa Rica (Fig. 8D), in contrast, the Fila de Cal carbonate platform lasted much longer, from Middle Eocene up into the Lower Oligocene (Rupelian), and also it could extend the most to build a vast frontal arc platform over $180 \mathrm{~km}$ along the Pacific arc area. During this time favorable shallow-marine conditions disengaged from strong volcaniclastic input from inner volcanic arc areas established Costa Rica's largest carbonate platform environment.

\section{Nature of the Fila de Cal Platform Substrate}

On which substrate did the Fila de Cal platform evolve? The basement in the frontal arc area of Costa Rica is predominantly of basaltic composition. Although it is not directly exposed in the study area, it crops out just $10 \mathrm{~km}$ south of it on the southern side of Río Sierpe (Fig. 2). Insights on its basaltic nature provide the rock fragments contained in the oldest, Middle Eocene, Eoannularia eocenica facies. The limestone bears accessory but significant content of juvenile basaltic lava fragments probably derived from basaltic basement (Fig. 8A). On such a basement used to accumulate similar Eocene and even older arc platform sequences, e.g., the Lutetian carbonate sequence of the Parritilla Formation (Bolz and Calvo, 2002) (Fig. 7). The same is true for the Upper Paleocene Ranikothalia limestones overlaying basaltic rocks and sedimentary cover strata in Cerro Espíritu Santo and Fila Chonta, in NW and central Costa Rica, respectively (Calvo and Bolz, 1991).

\section{CONCLUSIONS}

The microfacies analysis and larger foraminiferal assemblages from the Fila de Cal Formation reveal three different and biostratigraphically successive carbonate platform facies within the limestone sequence: (1) Eoannularia eocenica facies from the middle Eocene, (2) Lepidocyclina tobleri panamensisLepidocyclina chaperi facies from the upper Eocene and (3) Lepidocyclina yurnagunensisLepidocyclina undosa facies from the lower Oligocene. Altogether record continuous carbonate sedimentation in the neritic arc area over 14 to 19 m.y., representing the most remarkable climax episode the sedimentary record documents in southern Central America so far. The carbonate platform origin coincides with fast convergence rates of the Farallón 

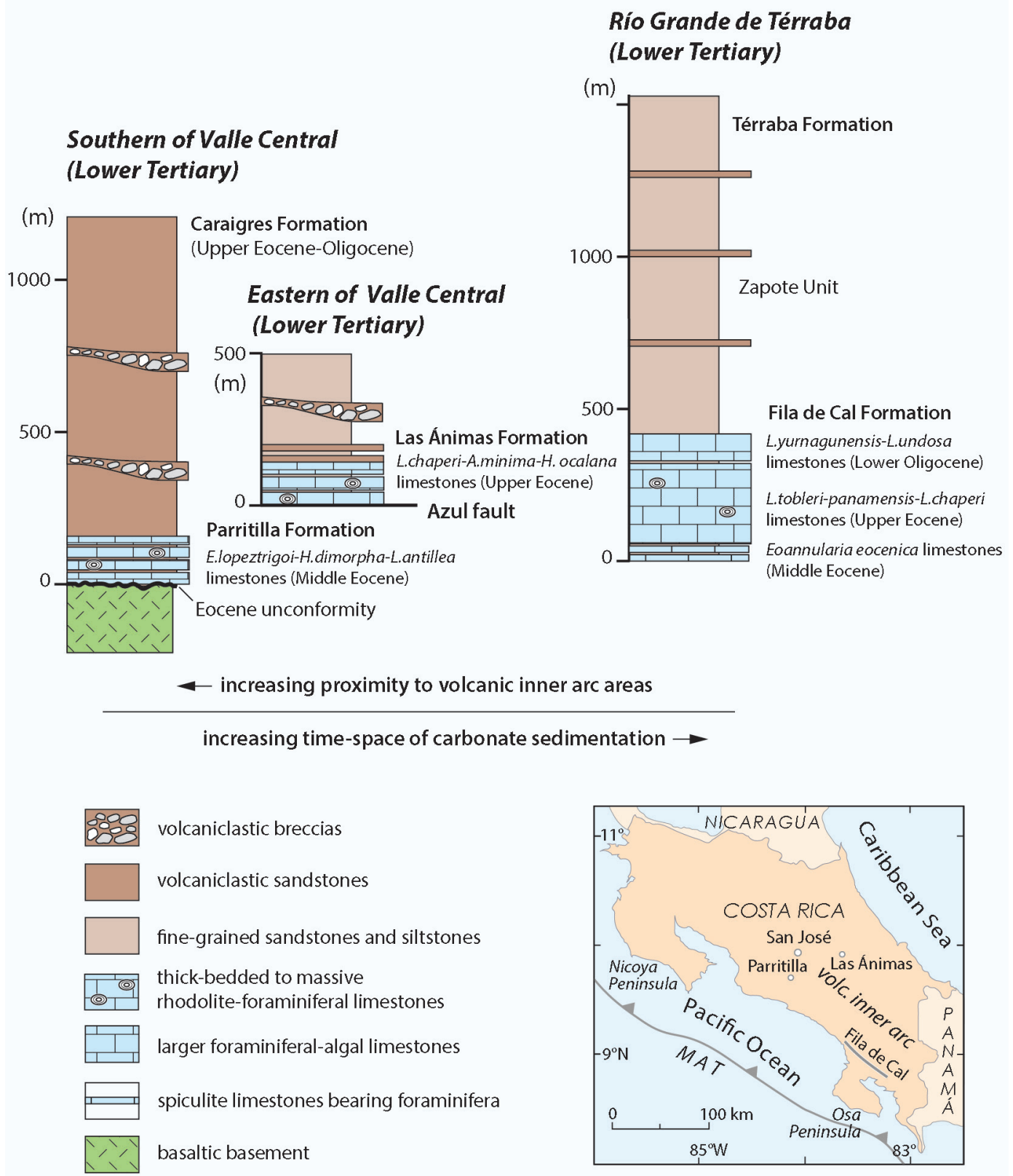

Fig. 7: Stratigraphic correlations among representative Eocene carbonate sequences of Costa Rica. The proximity to the active volcanic arc areas that the sequences volcaniclastic deposits record seem to have strongly controlled growing and persistence of sedimentary carbonate platform environments. Inset tectonic map shows location of carbonate sequences within the volcanic arc. MAT: Middle America Trench. The Parritilla sequence is after Rivier and Calvo (1988), Denyer and Arias (1991) and Bolz and Calvo (2002); Las Ánimas sequence after Rivier (1973) and Fernández (1987). Larger foraminiferal assemblages and limestone ages are from Bolz and Calvo (2002) and newly determinations in this study, including own observations on Las Ánimas limestone samples from the Formation's type locality. Previous age determination of Las Ánimas and Fila de Cal limestones are from Cole (1953) and Malavassi (1961). Strata thickness is not at scale. 


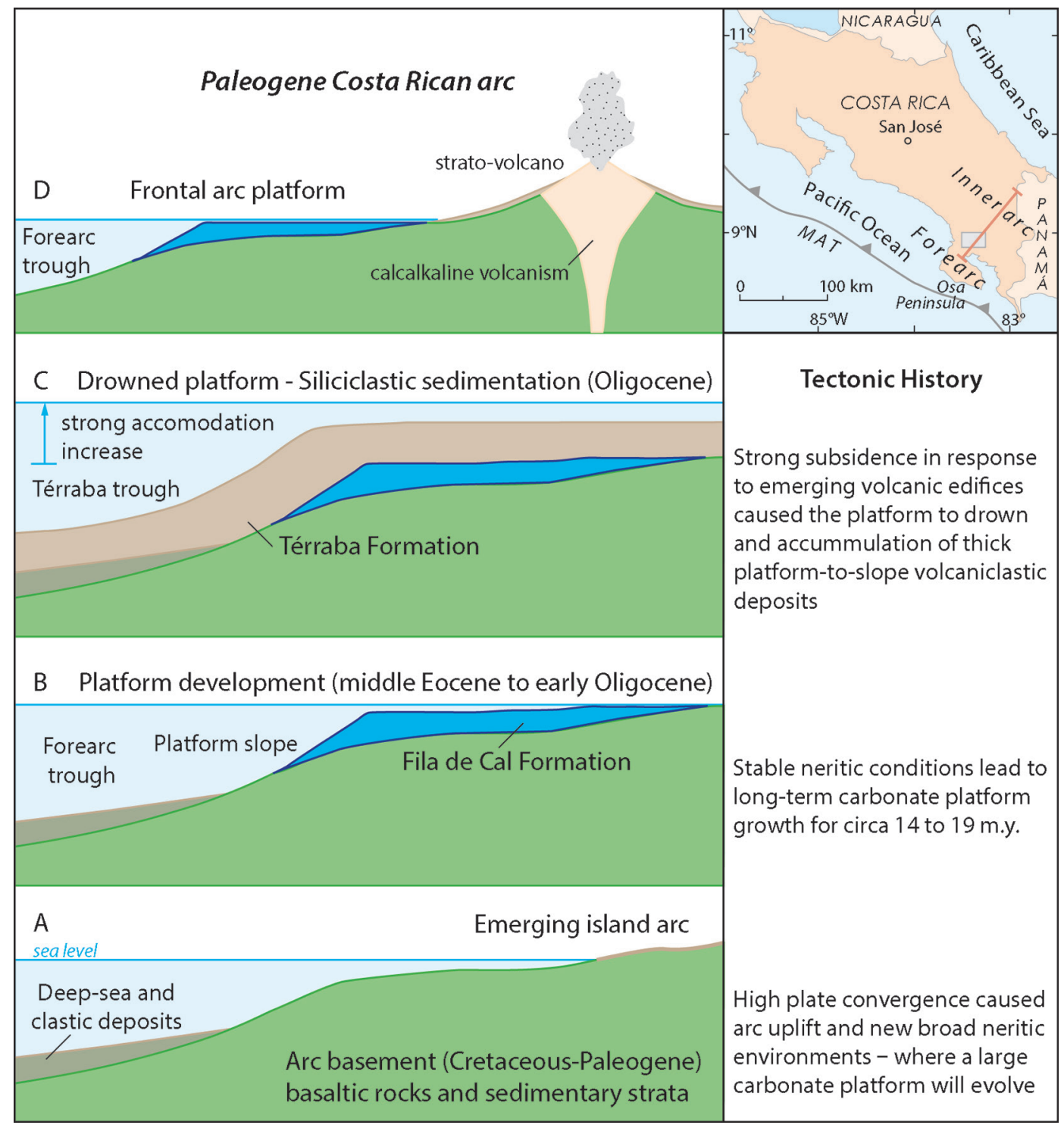

Fig. 8: Cartoon depicting the origin and tectonic history of the Fila de Cal carbonate platform (A-C). The carbonate platform grew in the Pacific frontal arc area to build the arcward boundary of the forearc trough (D). Inset map shows the study area and tectonic setting of southern Costa Rica. See text for discussion.

plate beneath southern Central America. The correlation with further contemporaneous carbonate arc sequences indicates the Fila de Cal platform decline in the Oligocene responds to tectonic arc-wide history rather than local basin tectonics. Primarily the strong subsidence caused by new emerging volcanic edifices and the proximity to the active volcanic inner arc areas were probably the main factors controlling growing and persistence of marine carbonate environments within the intraoceanic arc setting. 


\section{AKNOWLEGMENTS}

The first author wants to express her gratitude to M. Pécheux and posthumously to L. Hottinger for their helpful first look at the foraminifera contained in some samples from the Fila de Cal limestones that introduced her to the study of larger foraminifera in the early days. We extend our gratitude to S. Mora for the useful reference data on the Río Savegre limestones and his manuscript review as well. We also gratefully thank R. Schmidt-Effing, A. Alfaro, T. Aguilar and P. Denyer for their helpful manuscript reviews.

\section{REFERENCES}

Barker, R. W. and Grimsdale, T. F. (1936). A contribution to the phylogeny of the orbitoidal foraminifera, with description of new forms from the Eocene of Mexico. Journal of Paleontology, 10(4), 231-247.

Berrangé, J. P. (1989). The Osa Group: An auriferous Pliocene sedimentary unit from the Osa Peninsula, southern Costa Rica. Revista Geológica de América Central, 10, 67-93.

Bolz, A. and Calvo, C. (2002). Calizas lutetianas del arco interno Paleógeno de Costa Rica. Revista Geológica de América Central, 26, 7-24.

BouDagher-Fadel, M. K. (2008). Evolution and geological significance of larger benthic foraminifera. Developments in Paleontology \& Stratigraphy, 21.

Butterlin, J. (1981). Claves para la determinación de macroforaminiferos de México y el Caribe, del Cretácico Superior al Mioceno Medio. México: Instituto Mexicano del Petroleo.

Calvo, C. (1987). Las calizas neríticas de la vertiente pacifica del norte de Costa Rica y sur de Nicaragua: épocas y sistemas asociados a la apertura y evolución del margen convergente de la América Central meridional (Unpublished licenciatura thesis). Universidad de Costa Rica, San José, Costa Rica.

Calvo, C. and Bolz, A. (1991). La Formación Espíritu Santo (Costa Rica): sistemas de plataforma carbonatada autóctona del Paleoceno superior-Eoceno inferior. Revista Geológica de América Central, 13, 91-95.

Calvo, C. and Bolz, A. (1994). Der älteste kalkalkaline Inselbogen-Vulkanismus in Costa Rica. Marine Pyroklastika der Formation Loma Chumico (Alb bis Campan). Profil, 7, 235-262.

Cole, W. S. (1953). Larger Foraminifera from the upper Eocene of Costa Rica. Journal of Paleontology, 27, 748-749.

Cole, W. S. (1960). Revision of Helicostegina, Helicolepidina and Lepidocyclina (Polylepidina). Contributions of the Cushman Foundation to Foraminifera Research, 11, 57-63.

Cushman, J. A. (1948). Foraminifera. Their classification and economic use. Cambridge, Massachusetts: Harvard Univ. Press.

Daly, M. C. (1989). Correlations between Nazca/ Farallón plate kinematics and forearc basin evolution in Ecuador. Tectonics, 8(4),769-790.

Dengo, G. (1960). Notas sobre la geología de la parte central del litoral Pacífico de Costa Rica. Informe Semestral del Instituto Geográfico Nacional, Julio-Dic., 46-63.

Dengo, G. (1962). Estudio geológico de la región de Guanacaste, Costa Rica. Inst. Geogr. Nacional, San José.

Denyer, P. and Arias, O. (1991). Estratigrafía de la region central de Costa Rica. Revista Geológica de América Central, 12, 1-59. 
Di Marco, G. (1994). Les terrains accretes du Sud du Costa Rica - Évolution tectonostratigraphique de la marge occidentale de la plaque Caribe (Unpublished dissertation). Université de Lausanne, Lausanne, Switzerland.

Domínguez, R. A. (1978). Estudio preliminar de la geología del sitio de presa, proyecto Fortuna, y observaciones geotécnicas (Unpublished licenciatura thesis). Universidad de Costa Rica, San José, Costa Rica.

Dunhan, R.J. (1962). Classification of carbonate rocks according to depositional texture. In: Ham, W.E. (ed.) Classification of Carbonate Rocks. American Association of Petroleum Geologists Memoir. 1, 108-121.

Engebretson, D. C., Cox, A. and Gordon, R. G. (1985). Relative Motion between Oceanic and Continental Plates in the Pacific Basin. Special Publication of the Geological Society of America, 206, 1-52.

Eames, F. E., Clarke, W. J., Banner, F. T., Smout, A. H. and Blow, W. H. (1968). Some Larger Foraminifera from the Tertiary of Central America. Paleontology, 11, 283-305.

Embry, A. F. and Klovan, J. E. (1971). A late Devonian reef tract on northeastern Banks Island, N. M. T. Bulletin of the Canadian Petrol. Geology, 19(4), 730-781.

Fernández, J.A. (1987). Geología de la hoja topográfica Tucurrique (1:50000) (Unpublished licenciatura thesis). Universidad de Costa Rica, San José, Costa Rica.

Flügel, E. (1982). Microfacies Analysis of Limestones. Berlin: Springer.

Hallock, P. M. and Glenn, C. E. (1986). Larger Foraminifera: A Tool for Paleoenvironmental Analysis of Cenozoic Carbonate Depositional Facies. Palaios, 1, 55-64.
Hardenbol, J., etal.(1998). Mesozoic and Cenozoic Sequence Chronostratigraphy Framework of European Basins. In: De Graciansky et al. (eds.) Mesozoic and Cenozoic Sequence Stratigraphy Framework of European Basins. SEPM Special Publications 60: chart 5 Cretaceous Biochronostratigraphy.

Henningsen, E. (1966). Die pazifische Küstenkordillere (Cordillera Costeña) Costa Ricas und ihre Stellung innerhalb des süd-zentralamerikanischen Gebirges. Geotektonische Forschung. 23, 3-66.

Heywood, C. E. (1984). Forearc deformation in southern Costa Rica: A consequence of the collision of the aseismic Cocos ridge (Unpublished master thesis). University of California, California, USA.

Hinz, K, von Huene, R., Ranero, C. R. and Pacomar Working Group. (1996). Tectonic structure of the convergent Pacific margin off Costa Rica from multichannel seismic reflection data. Tectonics, 15, 54-66.

Lew, L. R. (1983). The Geology of the Osa Peninsula, Costa Rica: Observations and Speculations About the Evolution of Part of the Outer Arc of the Southern Central American Orogen (Unpublished master thesis). Pennsylvania State University, Pennsylvania, USA.

Lundberg, N. (1991). Detrital record of the early Central American magmatic arc: Petrology of intraoceanic forearc sandstones, Nicoya Peninsula, Costa Rica. Geological Society of America Bulletin, 103, 905-915.

Loeblich, A. R. and Tappan, H. (1964). Treatise on Invertebrate Paleontology, Part C: Protista 2, Sarcodina, Chiefly "Thecamoebians" and Foraminiferida. Kansas: The Geological Society of America and University of Kansas Press. 
Malavassi, E. (1961). Some Costa Rican larger foraminiferal localities. Journal of Paleontology, 35, 498-501.

Mora, S. (1979). Estudio geológico de una parte de la región sur-este del valle del General (Unpublished licenciatura thesis). Universidad de Costa Rica, San José, Costa Rica.

Mora, S. and Valdés, R. (1984). Estudio geológico-geotécnico preliminar - proyecto hidroeléctrico Savegre. San José: Instituto Costaricense de Electricidad. Unpublished report.

Ogg, J. G., Ogg, G. M., Gradstein, F. M. (2016). A Concise Geologic Time Scale 2016. Amsterdam: Elsevier.

Pécheux, M. J-F. (1984). Le Sénonian superiorTertiaire du Chiapas (SE Mexique) et ses macroforaminiferes (Unpublished $3^{\mathrm{e}} \mathrm{Cycle}$ Thesis). Université de Nice, Nice, France.

Phillips, P. J. (1983). Stratigraphy, sedimentology and petrologic evolution of Tertiary sediments in southwestern Costa Rica (Unpublished master thesis). Louisiana State University, Louisiana, USA.

Rivier, F. (1973). Contribución estratigráfica sobre la geología de la Cuenca de Limón, zona de Turrialba, Costa Rica. Publicaciones Geológicas del ICAITI, 4, 149-159.

Rivier, F. (1985). Sección geológica del Pacífico al Atlántico a través de Costa Rica. Revista Geológica de América Central, 2, 23-32.

Rivier, F. and Calvo, C. (1988). Terciario del sur del Valle Central: Sección estratigráfica del cerro Caraigres, provincia de San José,
Costa Rica. Revista Geológica de América Central, 9: 61-74.

Sprechmann, P., Astorga, A., Calvo, C. and Fernández, J. A. (1994). Stratigraphic chart of the sedimentary basins of Costa Rica, Central America. Profil, 7, 427-433.

Stichler, J. C., Fisher, D. M., Gardner, T. W. and Protti, M. (2007). Constraints on inner forearc deformation from balanced cross sections, Fila Costeña thrustbelt, Costa Rica. Tectonics. doi:10.1029/2006CT001949

Tournon, J. and Alvarado, G. A. (1995). Carte géologique de Costa Rica, échelle 1:500000. La Vigie, Dieppe, France.

Weyl, E. (1980). Geology of Central America. Beiträge zur regionalen Geologie der Erde. Berlin, Stuttgart: Gebrüder Borntraeger.

Ulloa, A., Aguilar, T., Goicoechea, C. and Ramírez, R. (2011). Descripción, clasificación y aspectos geológicos de las zonas kársticas de Costa Rica. Revista Geológica de América Central, 45: 53-74.

Von Huene, R. and Flüh, E. (1994). A review of marine geophysical studies along the Middle America trench off Costa Rica and the problematic seaward terminus of continental crust. Profil, 15, 143-159.

Yuan, P. B. (1984). Stratigraphy, sedimentology and geological evolution of eastern Térraba trough (Unpublished $\mathrm{PhD}$. thesis). Louisiana State University, Louisiana, USA.

Yuan, P. B. and Lowe, D. R. (1987). Forearc sedimentation in Térraba trough, Costa Rica, Central America. Abstract, American Association of Petroleum Geologists Bulletin.71, 630. 